\title{
Oropharyngeal Squamous Cell Carcinoma Treatment in the Era of Immune Checkpoint Inhibitors
}

\author{
Peter L. Stern ${ }^{1, *}$ and Tina Dalianis ${ }^{2}$ \\ 1 Manchester Cancer Research Centre, University of Manchester, Manchester M20 4GJ, UK \\ 2 Department of Oncology-Pathology, Karolinska Institutet, Bioclinicum J6:20, Karolinska University Hospital, \\ 17164 Stockholm, Sweden; tina.dalianis@ki.se \\ * Correspondence: peter.stern@manchester.ac.uk
}

Citation: Stern, P.L.; Dalianis, T. Oropharyngeal Squamous Cell Carcinoma Treatment in the Era of Immune Checkpoint Inhibitors. Viruses 2021, 13, 1234. https:// doi.org/10.3390/v13071234

Academic Editor: Zhi-Ming Zheng

Received: 6 May 2021

Accepted: 24 June 2021

Published: 25 June 2021

Publisher's Note: MDPI stays neutral with regard to jurisdictional claims in published maps and institutional affiliations.

Copyright: (c) 2021 by the authors. Licensee MDPI, Basel, Switzerland. This article is an open access article distributed under the terms and conditions of the Creative Commons Attribution (CC BY) license (https:// creativecommons.org/licenses/by/ $4.0 /)$.
Abstract: While head and neck squamous cell carcinomas (HNSCC) are marginally decreasing due to the reduction in exposure to the major risk factors, tobacco and alcohol, the incidence of high-risk human papillomavirus (HPV)-positive oropharynx squamous cell carcinomas (OPSCC), especially those in the tonsil and base of tongue subsites, are increasing. Patients with the latter are younger, display a longer overall survival, and show a lower recurrence rate after standard-of-care treatment than those with HPV-negative OPSCC. This may reflect an important role for immune surveillance and control during the natural history of the virally driven tumour development. Immune deviation through acquisition of immune-suppressive factors in the tumour microenvironment (TME) is discussed in relation to treatment response. Understanding how the different immune factors are integrated in the TME battleground offers opportunities for identifying prognostic biomarkers as well as novel therapeutic strategies. OPSCC generally receive surgery or radiotherapy for earlystage tumour treatment, but many patients present with locoregionally advanced disease requiring multimodality therapies which can involve considerable complications. This review focuses on the utilization of newly emerged immune checkpoint inhibitors (PD-1/PD-L1 pathway) for treatment of HNSCC, in particular HPV-positive OPSCC, since they could be less toxic and more efficacious. PD-1/PD-L1 expression in the TME has been extensively investigated as a biomarker of patient response but is yet to provide a really effective means for stratification of treatment. Extensive testing of combinations of therapeutic approaches by types and sequencing will fuel the next evolution of treatment for OPSCC.

Keywords: oropharyngeal squamous cell carcinomas (OPSCC); human papillomavirus (HPV); tumour microenvironment (TME); immune checkpoint inhibitors; programmed death receptor-1 (PD-1) and ligand -1(PD-L1); T cell effectors; myeloid-derived suppressor cells (MDSC); macrophages; dendritic cells (DC)

\section{Introduction}

Head and neck cancers originating in the oral cavity, larynx, pharynx (hypopharynx, nasopharynx, or oropharynx), and in the sinonasal tract are $90 \%$ squamous cell carcinomas (SCC) [1-4]. This is the eighth most common malignancy worldwide in 2018, and overall survival (OS) for localized cancers is more than $90 \%$ for salivary gland and mucosal lip sites but closer to $60 \%$ for laryngeal and hypopharyngeal sites [5]. The principal associated risk factors are tobacco use, alcohol consumption, high risk (HR) human papillomavirus (HPV) infection (for OPSCC), and Epstein-Barr virus (EBV) infection (for nasopharyngeal squamous cell carcinoma) [1-4]. When the upper aerodigestive tract is chronically exposed to these carcinogenic elements, dysplastic lesions can develop in the oropharyngeal mucosa and such premalignant neoplasia is a precursor for malignant tumours. The relative prevalence of these risk factors contributes to the variations in the observed distribution of head and neck squamous cell carcinomas (HNSCC) in different areas of the world [1-4]. 
Unsurprisingly, HNSCC are a very heterogenous group of cancers which demonstrate different pathologies, prognoses, and treatment options [5]. Genomic analysis of HNSCC has provided comprehensive lists of associated mutations/genetic changes (single nucleotide, confined insertions/deletions, larger alterations including gains and losses from arms of or entire chromosomes) [2,6]. The picture that emerges for HPV-negative HNSCC is of some key driver somatic gene mutations, with each generally associated with considerably less than a quarter of tumours (with the exception of TP53, which is present in a majority $(72 \%))$, which then are manifest on a background of other diverse, including passenger, mutations. Most of the driver events inhibit the action of tumour suppressor functions on the cell cycle (p16INK4A; p53), survival (PTEN), WNT signalling (protocadherinFAT1; LIM domain-containing protein AJUBA; NOTCH1), and epigenetic regulation (histone-lysine $\mathrm{N}$-methyltransferases KMT2D and NSD1). Acquisition of oncogenic action on the cell cycle (G1-S-specific cyclinD1), epidermal growth factor receptor (EGFR), and survival have also been documented in some subsets of HPV-negative HNSCC $[2,6]$.

\section{Oropharyngeal Squamous Cell Carcinomas (OPSCC)}

The incidence of HNSCC located at most oral sites is actually marginally decreasing because of the reduced exposure to the tobacco and alcohol risk factors associated with its development. By contrast, the incidence of OPSCC associated with HR HPV is increasing, particularly in young men, which is most apparent in Northern Europe and North America and believed to be the consequence of oral sexual behaviour [5,7]. For SCC originating in the oropharynx, tonsil, and base of the tongue (OPSCC), HR HPV, principally HPV 16, accounts for $>80 \%$ of the tumours [8,9]. Importantly, patients with HPV16-positive OPSCC display a longer OS and a lower recurrence rate after SOC treatment than patients with HPV-negative OPSCC [7]. Since HPV-related OPSCC behaves differently as a disease when compared to HPV-negative OPSCC, a separate staging system has been developed [10,11]. The assignment to HPV-positive is frequently inferred from p16 immuno-histochemistry whereby the expression of p16 is constitutively unregulated by HPV oncogene suppression of $\mathrm{Rb}$ [12]. This type of measure is not fool-proof and additional, more direct, measures of HPV through nucleic acid detection can significantly improve specificity, but gold-standard detection of hr HPV oncogene RNA is unfortunately not regularly utilised [13].

For TNM staging (see Legend Table 1), while the T categories for HPV-positive and HPV-negative OPSCC are similar, a T0 level (unknown primary) category is only used in p16-positive metastatic nodes, where the primary is presumed an OPSCC, and the T4b category has been removed from p16-positive OPSCC. For clinical N staging of p16positive disease: $\mathrm{N} 1$ is ipsilateral nodes (one or multiple), but none larger than $6 \mathrm{~cm}$, N2 is contralateral or bilateral nodes less than $6 \mathrm{~cm}$, and N3 is when nodes are greater than 6 $\mathrm{cm}$. Pathological staging is only available to patients where surgery is possible, and for HPV-related (p16-positive) OPSCC the number of positive nodes between 1 and 4 vs. 5 or more impacts outcome, so this is reflected in $\mathrm{pN}$ staging. A summary of the clinical and pathological prognostic stage groups is shown in Table 1 [11].

The natural history of HPV-mediated carcinogenesis in HNSCC is not precisely documented. However, in squamous epithelium of the transformation zone of the cervix, about $20 \%$ of hr HPV infections result in dysplastic lesions, and the major risk factor for cancer progression is persistent infection [14]. In cases where the normal viral life cycle is aborted and expression of the viral oncogenes E6 and E7 is elevated (e.g., through integration of the virus in cell genome), cell proliferation is stimulated. This virally driven cellular proliferation is causally linked to malignant transformation through unregulated E7 expression degrading the host cell retinoblastoma pocket proteins (RB), inducing S-phase-related molecular changes, with viral E6 binding to and degrading p53 to prevent apoptosis of unscheduled S-phase entry [15]. This leads to a reduced control of the cell cycle which would usually allow for DNA repair of any genetic errors. Any accumulation of mutations can provide advantage for transformation to high-grade cervical intraepithelial neoplastic lesions $[15,16]$. 
Table 1. AJCC prognostic clinical or pathological stage groups for HPV-related (p16-positive) oropharyngeal cancers [10,11].

\begin{tabular}{|c|c|c|}
\hline Stage & Clinical & Pathological \\
\hline $\mathrm{I}$ & T0N1M0, T1N0M0, T1N1M0, T2N0M0 or T2N1M0 & T0N1M0, T1N0M0, T1N1M0, T2N0M0 or T2N1M0 \\
\hline II & $\begin{array}{l}\text { T0N2M0, T1N2M0, T2N2M0, T3N0M0, T3N1M0 or } \\
\text { T3N2M0 }\end{array}$ & $\begin{array}{l}\text { T0N2M0, T1N2M0, T2N2M0, T3N0M0, T3N1M0, } \\
\text { T4N0M0 or T4N1M0 }\end{array}$ \\
\hline III & $\begin{array}{c}\text { T0N3M0, T1N3M0, T2N3M0, T3N3M0, T4N0M0, } \\
\text { T4N1M0, T4N2M0 or T4N3M0 }\end{array}$ & T3N2M0, or T4N2M0 IV Any T, any N and M1 \\
\hline IV & Any $\mathrm{T}$, any $\mathrm{N}$ and $\mathrm{M} 1$ & \\
\hline \multicolumn{3}{|c|}{$\begin{array}{l}\text { Legend: A general categorization assigns cancers as stage } 0 \text { (abnormal cells are present but with no spread); stages I-III (increasing size and } \\
\text { local spread), and stage IV (spread to distant sites). Additional information is provided by the TNM system: T refers to the size and extent } \\
\text { of the main or primary tumour, N to the number of nearby lymph nodes that have cancer, and M to whether the cancer has metastasized. } \\
\text { Further information is reflected in numbered subdivisions. Thus TX: main tumour cannot be measured; T0: primary tumour cannot be } \\
\text { found; and T1, T2, T3, T4: refer to the size and/or extent of the main tumour. The higher the number after the T, the larger the tumour or the } \\
\text { more it has grown into nearby tissues. Tumours may be further divided to provide more detail, such as T3a and T3b. Likewise, for regional } \\
\text { lymph nodes (N): NX: cancer in nearby lymph nodes cannot be measured; No: there is no cancer in nearby lymph nodes; N1, N2, N3: refer } \\
\text { to the number and location of lymph nodes that contain cancer. The higher the number after the N, the more lymph nodes that contain } \\
\text { cancer. For distant metastasis (M): MX: metastasis cannot be measured; M0: cancer has not spread to other parts of the body; M1: cancer } \\
\text { has spread to other parts of the body. Recent modifications in the T classification for some tumours include the depth of invasion (DOI) } \\
\text { of the primary (increase category by } 1 \text { level for each } 5 \mathrm{~mm} \text { of depth) and new refinements on the N categorisation utilising pathological } \\
\text { (histology) and/or clinical (imaging) to measure extra-nodal extension (ENE). Cut-offs define changes in staging level or a new sublevel. } \\
\text { Pathology-driven measures can be assessed and validated retrospectively, but this is more difficult for clinically based approaches for there } \\
\text { is no precedent and the imaging modalities have very different sensitivities and specificities. For example, a clinical estimation of depth of } \\
\text { invasion may overestimate by } 1-2 \mathrm{~mm} \text {, and contribution to size of lesion through inflammation or ulceration cannot be distinguished. }\end{array}$} \\
\hline
\end{tabular}

The productive versus transforming fate of an HPV infection may be dependent on the infected cell type of origin. For example, it has been suggested that specific single-layered epithelial cells of embryonic origin at the cervical squamocolumnar junction constitute highly susceptible cells for transforming infections and the origins of cancers [17]. For OPSCC, no obvious virus-infected premalignant lesions have yet been identified, but it is very likely that the natural history of oncogenesis is similar. As documented for cervical cancer, molecular changes in genes of the PI3K pathway are the most frequent genetic alterations found in HPV-driven HNSCC [6,18]. The PI3K signalling pathway affects translation and transcription of multiple targets that are involved in proliferation, survival, and motility [19]. However, while PIK3CA alterations appear more common in HPV-positive HNSCC, these are also detected in HPV-negative OPSCC; oncogenic PI3K signalling seems to constitute a driver for many HNSCC, independent of HPV involvement [6]. Genomic profiling of HPV-positive OPSCC shows evidence of heterogeneity in patterns of altered gene expression [20].

\section{Standard of Care (SOC) for OPSCC}

Surgical treatment, especially with recent advances in transoral robotic surgery of OPSCC, can sometimes be curative if the tumour is relatively small, has not spread, and is easily accessible, although these procedures are not without risks and quality of life sequelae [21]. Unfortunately, a majority of OPSCC patients present with locoregionally advanced (LA) disease for which a multimodality therapeutic approach including radiotherapy (RT) or chemo-RT (CRT) with or without surgery is usually employed [22-24].

CRT avoids surgery-associated risks, but there are frequently other complications including widespread tissue damage/toxicity in the head/throat region, including significant impacts for speech and swallowing, plus increased risk for secondary malignancies [25]. Furthermore, the use of cetuximab, a monoclonal antibody against epidermal growth factor receptor (EGFR), in combination with cisplatin or carboplatin and 5-fluorouracil (5FU) as a first-line treatment of recurrent/metastatic (R/M) HNSCC (EXTREME) has some utility with improved overall survival compared to platinum plus 5FU treatment with a response rate in about one third of patients [26]. Clearly there is a requirement to minimise toxicities and avoid the late complications, particularly in the younger patients with HPV-positive OPSCC, with its better prognosis $[7,27]$. To summarize, OPSCC generally receive RT 
or surgery for early-stage tumour treatment with combination therapies used for more advanced cancers.

Consequently, in spite of improvements in diagnostics, treatment, and surveillance, the 5-year progression-free survival (PFS) of patients with HPV-negative OPSCC with LA disease is $\sim 40-50 \%$, and survival rates for $\mathrm{R} / \mathrm{M}$ disease have not significantly changed over the past years [5]. Advanced-stage HPV-positive OPSCC patients have five-year survival rates of $75-80 \%$, vs. $<50 \%$ among patients with similarly staged HPV-negative tumours [7]. With R/M disease having such a poor prognosis there is clearly an urgent need to identify biomarkers for detection of early disease, accurate prediction of prognosis, and appropriate selection of therapy.

In 2018, The National Comprehensive Cancer Network Clinical Practice Guidelines in Oncology (NCCN, USA) defined some modifications of treatment plans for p16-positive vs. HPV-negative OPSCCs [28]. However, the options recommended in most cases did not vary except where as an alternative to definitive RT alone or surgery alone, treatment with RT plus systemic therapy was recommended for T1 N1 p16-negative but not for p16-positive tumours with a single node $\leq 3 \mathrm{~cm}$. Overall, all OPSCC should receive RT or surgery for early-stage tumour treatment with combination therapies used for more advanced cancers. For example, platinum-based chemotherapy (CT) with RT reduces HNSCC and the OPSCC subgroup patient mortality by $26 \%$, yielding an $8 \%$ absolute 5 -year survival benefit [29]. However, using cisplatin plus RT showed significant increases in both acute and late toxicity. There was a lot of enthusiasm to test whether a de-escalation of SOC therapies could deliver a significant reduction in the side effects (toxicity) of the treatments plus an improvement in quality of life, but without any loss of efficacy. The logic was that the distinct tumour biology of HPV-positive OPSCC with their better prognosis derived from a possibly higher treatment sensitivity.

Several early phase clinical trials investigated whether response to induction CT could select patients with stage III-IV HPV-positive OPSCC for reduced-dose radiation. Indeed, patients with a complete response to induction CT retained cancer control with reduced radiation doses, but with reduced swallowing and nutritional problems [30,31]. Additional trials are probing de-escalated treatments for HPV-positive OPSCC. These include reduceddose radiation and/or $\mathrm{CT}$, stratifying by response to induction $\mathrm{CT}$, stratification for any follow-up loco-regional therapy, efficacy of CT or RT as alternatives to surgery, minimally invasive transoral robotic surgery using pathology to stratify patients for de-escalation (and using targeted therapies) [28]. One such randomised, prospective clinical trial recruited only patients with LA HPV-positive OPSCC and was designed to investigate non-inferiority of efficacy accompanied by reduction in acute and late therapy toxicity where cetuximab was substituted for cisplatin [32]. Previous work had provided support for the value of cetuximab when added to RT for locoregional control and survival in LA HNSCC [30]. Unfortunately, the RT plus cetuximab treatment was inferior to SOC (RT, cisplatin) and increased the risk of cancer progression and death and loss of locoregional control without any significant influence on overall toxicities [32]. It is worth pointing out, however, that this needs to be tested in HPV-negative OPSCC where EGFR amplification, overexpression, and downstream signalling are more frequent in contrast to HPV-positive cancers, where mutations downstream of EGFR (e.g., activating in PIK3CA) are more frequent and could mediate resistance to cetuximab.

The recognition of the potential of immunotherapies in cancer treatment, including checkpoint inhibitors, has stimulated the investigation of biomarkers relating to immune parameters and their importance in HNSCC. The next sections discuss the evidence of immune dysfunction in OPSCC and the use of checkpoint inhibitors in treatment. The value of immune biomarkers assessments in the optimal deployment of treatments involving checkpoint inhibitors for OPSCC treatment, especially due to the differences in outcome depending on HPV status, is also discussed. 


\section{Biomarkers in OPSCC}

Investigation and validation of any potential tumour biomarkers could be of great value in prognostication and therapy selection and refinement for patients with OPSCC. There are challenges in utilising the extensive genomic information for biomarker application which arise from heterogeneity in the patterns of expression both within individual tumours and between HNSCC tumours. Differences in clinical outcomes for OPSCC are likely to involve multiple factors including differential radio/chemosensitivity and genetic heterogeneity [33-35], but it is also possible that activation of local oropharyngeal immunity has a role in limiting the spread of the disease and/or enhancing response to therapy.

The important role of the immune system in the surveillance and control of neoplasia is now widely recognized [36,37]. Additionally, the subversion of such immune control through acquisition of immune suppressive factors in the tumour microenvironment (TME) is established as significant to cancer progression and poor treatment response, but understanding this also offers therapeutic opportunities [38-41]. The complex interactions at play in the natural history of an OPSCC are reflected in the emerging gene-expression profiles, which distinguish epithelial-mesenchymal transition (EMT), immune-related, keratinocyte differentiation, and oxidation stress factors with possible links to differential outcomes under investigation [4]. Detailed investigations of the types and proportions of immune cells and their interactions in the TME and any links to clinical performance following different treatments could provide the means for improved patient management. Any practical biomarker must have sufficient specificity and sensitivity, allowing clinically useful positive and/or negative predictive value, and be implementable in the clinical setting.

\section{Immune Deviation \\ Lessons from Cervical Neoplasia}

The lack of identifiable or accessible dysplastic precursor lesions limits our understanding of the natural history of HPV-driven neoplasia in OPSCC. However, based on our knowledge of HPV-associated cancers of the anogenital tract, in particular cervical neoplasia, there is clear evidence that the hr HPV infection of the target epithelium and the viral oncogene expression undermines the functioning of key elements of the innate immune system. This begins with a reduction of antigen-presenting cells which allows early virus immune evasion and persistence of infection. Over time, a multitude of interacting and self-reinforcing events actioned through modulation of different immune receptors, chemokine, and cytokine responses combine to generate an immune-suppressive microenvironment. This includes infiltration of immune-suppressive populations of Tregs, Th17, myeloid-derived suppressor cells (MDSCs), and upregulation of immune checkpoint receptor/ligand pathways [40-42]. All these changes constitute an immune deviation which can critically undermine the key $\mathrm{T}$ cell effector mechanisms capable of tumour control and elimination.

\section{Immune Infiltration of OPSCC}

\subsection{T-Lymphocytes}

Many investigations of whether the densities of various TME-infiltrating immune cells correlate with clinical outcomes in HNSCC have been performed [43-46]. Unsurprisingly, the inherent heterogeneity of the HNSCC with different prognoses plus the diversity and quality of immunohistochemical (IHC) analyses performed have yielded a wide range of results. A priori, the acquisition of diverse and cumulatively immunosuppressive factors will impact on tumour control and clinical performance in therapy. The question here is whether there are biomarkers from this set of parameters that can be useful for patient management, etc. Here, the focus is on OPSCC, where there are clear differences in patient clinical outcomes for HPV-positive and HPV-negative tumours.

Overall, there is a consensus for high levels of CD8+ and CD4+ T lymphocytes associating with better clinical responses to SOC treatment [46]. Thus, higher levels of infiltrating T cells have been documented in HPV-positive compared with HPV-negative OPSCC [47-50] 
(but not always [51,52]). However, when an increased T cell density was found in HPVpositive OPSCC it did not necessarily correlate with improved outcome. Interpretation of the results would be easier if there was consistency in the HPV typing methods and the techniques and reagents used to measure different immune factors in the TME. These should in particular include the precise location (tumour or stroma), the functionality of potential effectors, or the presence of other influences (secreted or cellular) which might counteract any anti-tumour activity. A study that assessed the relative infiltration in the tumour and the associated stroma reported a significant correlation of stromal infiltration by CD8+ T cells with better clinical outcome in HPV-positive OPSCC [43]. Evidence from cervical neoplasia has associated $\mathrm{T}$ cell infiltration of the epithelium as the key to lesion regression [53] and that the stroma may be the point of entry for such effector cells [54,55], possibly associated with activation of relevant gene expression in the stroma [56].

Of course, an alternative tumour-driven inflammatory influence can lead to the secretion of cytokines able to recruit other types of immunosuppressive cells to the TME. For example, Tregs contribute to control of immunological tolerance but can also play a role in facilitating cancer progression through suppression of anti-tumour immune responses. For HNSCC, including OPSCC, there is conflicting evidence regarding their role in suppressing tumour immunity and survival [57]. In part, this reflects the inadequacy of the markers used to identify Tregs either in the tissues or the peripheral blood plus lack of information on their functional status [46].

The inflammatory milieu of the TME plus the relative proportions of, e.g., $\mathrm{T}$ cell effector or suppressor cells populations are likely to influence the clinical outcomes of the patients. For example, studies have associated higher interferon gamma but lower interleukin-4 and transforming growth factor-beta levels in HPV-positive compared to HPVnegative OPSCC [58]. The presence in the TME of IFN-gamma-producing CD4+ and CD8+ $\mathrm{T}$ cells, inferred from expression of the transcription factor Tbet, has shown association with improved OS [45,59], while the presence of non-T cell IL-17-producing cells was linked to poorer survival [60]. Paradoxically, in one study, Tbet-positive Tregs were shown to accumulate in HPV16-positive OPSCC and the patients showed improved survival to SOC therapy [61]. Importantly, in such good responder patients, the Tbet-expressing intratumour populations of Tregs correlated with the levels of Tbet-positive CD4+ and CD8+ T cells and the detection of HPV-specific T cells. Such results are consistent with the characteristics of a $\mathrm{T}$ helper 1 type biased immune response with balance of inflammatory conditions supporting anti-tumour activity [61].

The functionality of anti-tumour effector T cells in the TME can also be compromised by alterations in HLA expression by the tumour target cells [62]. In HPV-driven cancers, overexpression of E6/E7 oncogenes facilitates genomic instability, and any generated mutations that cause HLA class I down-regulation by tumour cells could be selected as a means for immune escape. However, such variation in HLA class I expression in HNSCC does not appear to correlate with clinical outcome [63,64]. Once again, the individual influence of a gross measure like HLA class 1 expression may be compromised by the heterogeneity and the integrated effect of a multiplicity of contributing factors. Interestingly, upregulation of HLA class II expression on HPV-positive OPSCC has been correlated with improved survival of such patients, consistent with a role for CD4 T cells in the control of OPSCC [65].

\subsection{Myeloid Cells}

Notably, the particular flavour of the inflammation can also influence the myeloid cell infiltrate and its functionality in the TME including by differentiation into macrophages, myeloid-derived suppressor cells (MDSC), or antigen-presenting dendritic cells (DC). Thus, when blood monocytes attracted to the TME differentiate into tumour-associated macrophages (TAM) they can provide either anti-tumour (M1) or tumour-promoting activity (M2) as driven respectively by the local levels of IFN gamma versus IL-4/IL-13 [66]. Furthermore, various secretions (TGF-beta, vascular endothelial growth factor (VEGF), 
IL-6, IL-10, prostaglandin E2 (PGE2), and chemokines) by the M2 macrophages act to promote tumour metastasis and Treg expansion with concomitant suppression of effector $\mathrm{T}$ cell activity [67]. Most importantly, in response to local IFN gamma production or hypoxia, TAM can upregulate inhibitory ligands of the immune checkpoint pathways which can limit anti-tumour T cell activity (see below). It is no surprise that there are investigations of OPSCC macrophage tumour infiltration and clinical outcome which support either a role in tumour control [67] or in promotion [65]; this can also differ in HPV-negative vs. HPV-positive tumours [63]. This lack of clarity most likely derives from the difficulty of distinguishing the functionality of macrophages in the context of all the other contributing factors. Some commonality for a positive contribution by TAM is probably favoured by the Th1 cell response flavour of local immunity in the TME [67].

MDSCs can be recruited from the blood or generated locally by arresting monocyte differentiation at an immature point. They can accumulate in different places in response to proinflammatory molecules (PGE2, IL-1 $\beta$, IL-6, VEGF, S100A8/A9 proteins, and the complement component $\mathrm{C} 5 \mathrm{a}$ ) produced by tumour cells or by host cells in the TME [68]. MDSCs suppress anti-tumour immunity through a variety of diverse mechanisms. T cell activation is suppressed by production of arginase and ROS, the nitration of the $\mathrm{T}$ cell receptor (TCR), cysteine deprivation, and the induction of Tregs. Innate immunity is impaired by the down-regulation of macrophage-produced IL-12, the increase in MDSC production of IL-10, and the suppression of natural killer (NK) cell cytotoxicity. Antigen presentation is limited by the expansion of MDSC at the expense of DC. Defining the monocytic MDSC phenotype requires multiple markers (CD14+ HLA-DR-CD33+ CD11b+) that are difficult to assess in TME in situ but can be assessed by flow cytometry to enumerate circulating levels [69,70]. High systemic levels of MDSC have been associated with recurrence in OPSCC patients [71], and a variety of depletion strategies are being investigated to potentially boost immunotherapeutic strategies [72]. A recent study has highlighted the need to monitor the dynamics of monocyte differentiation in the context of other populations of peripheral blood mononuclear cells (PBMC) [73]. Thus, an elevated monocyte count was detected before the initiation of treatment in the PBMC of OPSCC patients which correlated with poor prognosis. Dynamic changes in monocyte subsets were documented involving the immune checkpoint ligand PD-L1 expression on monocytes and monocyte-derived MDSCs. Other studies have investigated peripheral blood measures of T effector lymphocytes, but this has not generally correlated with the levels in the TME or reliably predicted clinical outcomes [51].

Finally, monocytes recruited into the TME can also differentiate into DCs and high numbers can be associated with good clinical outcomes [74]. As the primary antigenpresenting cells in the tumour, they can promote the numbers and sustained functionality of infiltrating cytotoxic T lymphocyte responses. It is generally thought that DCs in tumours capture tumour antigens and migrate to draining lymph nodes, where they prime and activate tumour-specific T cells. Memory and effector CTLs return to the tumour to perform immunosurveillance activities limiting tumour development and/or progression. Infectious disease models have established that antigen-experienced $\mathrm{T}$ cells require cognate interactions with tissue DCs to expand in situ and achieve full effector functions. Unfortunately, due to the immunosuppressive nature of the TME, plus their plasticity, tumour DCs are often dysfunctional, which in turn facilitates immune evasion. Indeed, it appears that the number, phenotype, and function of DCs can alter as a cancer develops with tumour-infiltrating DCs, macrophages, MDSCs, and T cells densities increasing but with a change from an immunostimulatory to an immunosuppressive DC phenotype [75].

\section{Immune Checkpoint Pathways}

Multiple inhibitory (e.g., PD-L1, TIM-3, LAG-3, CD200, and CTLA4) and activating (4-1BBL, ICOS-L, CD80, and CD86) immune regulatory molecules influence the activation, differentiation, and proliferation of $\mathrm{T}$ cells. $\mathrm{T}$ cell interactions with immature DCs can lead to $\mathrm{T}$ cell tolerance through various mechanisms, including deletion, anergy, and the 
generation of regulatory $\mathrm{T}$ cells $[76,77]$. Importantly, a class of inhibitory agents targeting some of these immune checkpoint pathways has been associated with sustained tumour responses in a variety of cancers [78]. The receptor-programmed death-1 (PD-1) interacting with its ligand PD-L1 is recognized as one dominant negative regulator axis of anti-tumour effector function whereby the interaction of PD-L1 leads to PD-1-mediated T cell exhaustion and inhibition of anti-tumour cytotoxic $\mathrm{T}$ cells. The stimulation of tumour specific $\mathrm{T}$ cells in the local tumour environment releases interferon gamma and this upregulates PD-L1 on the local tumour and other cells. This type of homeostatic mechanism is usually deployed to limit inflammation in a resolving lesion, but in the chronic tumour situation it can be subverted to compromise $\mathrm{T}$ cell function through adaptive immune resistance as discussed in more detail by others [79]. For more information on the subject, please also see a recent excellent review on emerging concepts in PD-1 checkpoint biology [80].

Blockade of the PD-1/PD-L1 axis by antibodies can reverse this immune suppression, and such single-agent therapies are now licensed treatment for several types of cancers [75, 81]. Expression of PD-L1 in tonsillar crypts has led to speculation that it might facilitate HPV infection at these sites and has therefore encouraged the use of PD-1 inhibitors in patients with HPV-positive tumours [82]. Some studies have shown that upregulation of PD-1 and/or PD-L1 in OPSCC is linked to stronger immune infiltration and a good prognosis following SOC treatment, possibly reflecting an effective ongoing anti-tumour immune response [83-86]. However, a recent meta-analysis of immunohistochemistry (IHC) analyses for PD-L1 expression showed a positivity rate of $36-48 \%$ for HNSCC; but while HPV-positive tumours showed a relatively increased PD-L1 expression, in neither case was the PD-L1 level linked with OS [87].

\section{Licencing of Immune Checkpoint Inhibitors for Treatment in HNSCC}

Building on encouraging early phase clinical studies in HNSCC, late phase III trials have now executed validation studies of several immune checkpoint inhibitor antibodies that block the PD-1/PD-L1 axis for the treatment of R/M HNSCC patients that failed a platinum-based therapy [88]. The illustrative results are summarized in Table 2 for two PD-1 inhibitors, both humanized IgG4s, nivolumab (OPDIVO, Bristol-Myers Squibb, New York, NY, USA), and pembrolizumab (KEYTRUDA, Merck Sharp \& Dohme, Kenilworth, NJ, USA), plus durvalumab (high affinity engineered IgG1 versus PD-L1). The phase III studies for nivolumab (CHECKMATE-141) [89] and pembrolizumab (KEYNOTE 040) [90] both showed a survival benefit as compared to standard monotherapy for diseases progressing less than 6 months after a platinum-based CT [88-90]. Long term results of the nivolumab CHECKMATE-141 study (minimum follow-up 24.2 months) confirmed a survival advantage with the 2-year rate almost 3-fold more, an increased durability of response, and much less toxicity [91]. For the KEYNOTE 040 study, the primary endpoint of increased OS was met with a median of 8.4 months for the pembrolizumab arm compared to 6.9 months in the standard arm, respectively, and first-year survival comparison was $37 \%$ vs. $26.5 \%$. The response rate is moderate at $14.6 \%$ in the pembrolizumab arm vs. $10.1 \%$ in the SOC arm, but with a very long median response duration in the pembrolizumab arm of 18.4 months and a better toxicity profile.

It is important to point out that any direct comparison of these trials is complicated by subtle differences in the patients recruited and the treatments provided in the standard therapy arms. However, the efficacy of these drugs in patients with R/M HNSCC revealed a relatively low overall response rate with no difference in response between HPV-positive and HPV-negative cancers. By apparent contrast, durvalumab in the EAGLE phase III study showed no significantly increased OS compared to SOC treatment, but this negative result probably results at least in part from unexpectedly good outcome in the control arm (SOC) patients. Interestingly, there is a lot of mortality in the early stages of this trial in the immunotherapy arm patients, but the fraction of these patients who survived showed increased duration of responses, better survival at 2 years, plus reduced toxicity to durvalumab relative to the SOC arm [92]. 
Table 2. Key immune checkpoint inhibitor clinical efficacy trials for HNSCC.

\begin{tabular}{|c|c|c|c|c|c|c|}
\hline Study [Ref] (No of Patients) & Drug v IC or SOC & $\begin{array}{c}\text { OS: Median (mo) HR } \\
(p \text { Value })\end{array}$ & $\begin{array}{c}1 \text { Year OS (\%) } 2 \text { Year OS } \\
(\%)\end{array}$ & $\begin{array}{c}\text { PFS: Median mo HR } \\
(p \text { Value })\end{array}$ & $\begin{array}{l}\text { Overall Response Rate } \\
\text { (\%) Median Duration } \\
\text { (mo) }\end{array}$ & $\%$ Toxicity Grade 3 \\
\hline $\begin{array}{c}\text { CHECKMATE-141 }[84,86] \\
\text { ( } n=506) \\
\text { Open Label, Randomized Phase } \\
3 \text { Trial of Nivolumab vs. } \\
\text { Therapy of IC in R/M } \\
\text { platinum-refractory HNSCC } \\
\text { (NCT02105636) }\end{array}$ & Nivolumab v IC & $\begin{array}{c}7.5 \text { v } 5.1 \\
0.70 * \\
(p=0.01)\end{array}$ & $\begin{array}{l}36.0 \mathrm{v} 16.6 \\
16.9 \mathrm{v} 6.0\end{array}$ & $\begin{array}{c}2.0 \mathrm{v} 2.3 \\
0.89 \\
(p=0.32)\end{array}$ & $\begin{array}{l}13.3 \text { v } 5.8 \\
9.7 \text { v } 4.0\end{array}$ & 13.1 v 35.1 \\
\hline $\begin{array}{c}\text { KEYNOTE-040 } \\
\text { [85] }(n=495) \\
\text { Phase III Randomized Trial of } \\
\text { Pembrolizumab vs. SOC in R/M } \\
\text { HNSCC patients (NCT02252042) }\end{array}$ & Pembrolizumab v SOC & $\begin{array}{c}8.4 \text { v } 6.9 \\
0.80 * \\
(p=0.0161)\end{array}$ & $\begin{array}{l}37.0 \text { v } 26.5 \\
\text { NA }\end{array}$ & $\begin{array}{l}2.1 \text { v } 2.3 \\
\text { NA }\end{array}$ & $\begin{array}{l}14.6 \text { v } 10.6 \\
18.4 \text { v } 5.0\end{array}$ & 13 v 36 \\
\hline $\begin{array}{c}\text { EAGLE [87] }(n=736) \\
\text { Phase III Randomized, } \\
\text { Open-Label, Durvalumab } \\
\text { monotherapy ( } \& \text { combination } \\
\text { with tremelimumab) vs. SOC in } \\
\text { R/M HNSCC patients } \\
\text { (NCT02369874) }\end{array}$ & Durvalumab v SOC & $\begin{array}{c}7.6 \mathrm{v} 8.3 \\
0.88 \\
(p=0.76)\end{array}$ & $\begin{array}{l}37.0 \text { } 30.5 \\
18.4 \mathrm{v} 10.3\end{array}$ & $2.1 \mathrm{v} 3.7 \mathrm{NA}$ & $\begin{array}{l}17.9 \text { v } 17.3 \\
12.9 \text { v } 3.7\end{array}$ & 10.1 v 24.2 \\
\hline
\end{tabular}


Unfortunately, the impact of immune checkpoint inhibitors is somewhat limited by the relatively low proportion of patients who respond, the need to manage potential autoimmune toxicities in some patients, as well as the high treatment costs. This highlights the value of a biomarker(s) that might allow for selection of patients who could most benefit from such immunotherapies. The obvious candidate has been to investigate whether the level of inhibitory molecule tumour expression can predict patient responses.

\section{PD-L1 Expression as a Prognostic in HNSCC and in Association to HPV Status}

PD-L1 expression has been widely investigated for use as a predictive marker in several solid tumours although the results have had limited value in clinical application thus far [93]. This is seen with HNSCC, where investigations of PD-L1 positivity within a tumour have not yielded consistent results in seeking any correlation to clinical responses. This reflects the problems derivative from the heterogeneity of tumours included in different studies (HNSCC, OPSCC, HPV status), the associated patient treatment schedules, as well as the reagents and detection methodologies, the definitions of positivity, the cut-off levels used, and the scoring system with inclusion of tumour cells alone (TPS: tumour proportion score) or all relevant cells expressing PD-L1 (CPS: combined proportion score). In addition, our current understanding of the biology of immune checkpoint control and the mechanisms of the agents that block these pathways is still very limited.

Even investigating the more homogeneous OPSCC tumours and stratifying by HPV status has been challenging for integration and interpretation of simple density measures of different cell types showing PD-L1 expression in TME with clinical outcomes to SOC. For example, populations identified as CD8+ T cells and CD68+ macrophages were both higher in HPV-positive compared to HPV-negative OPSCC. However, when subpopulations were identified with additional markers of the checkpoint pathway CD8+/PD-1 T cells were at similar levels but the proportion of CD68+/PD-L1/macrophages was lower in HPV-positive compared to HPV-negative OPSCC [94]. Indeed, in HPV-negative OPSCC patients, the increased PD-L1/macrophage levels were associated with better outcome [94].

Instead of simple enumeration of cell densities, analysing the spatial organisation of cells in the TME may be able to provide a more "functional" measure of immune regulation. Thus, an automated analysis pipeline was used to quantify the potential of $\mathrm{T}$ cells to interact with PD-L1 expressing cells in the TME. An algorithm was used that discarded artefacts and scanning errors, performed cell segmentation, and determined events defined by the proximity between cell subsets employing the hypothesised interaction distribution method. The results showed that a high frequency of spatial interactions between CD8+or PD-1-marked T cells and PD-L1'positive cells were prognostic for poor overall survival in patients with HPV-negative OPSCC [95]. Previous analyses of the same cohort using density measures of PD-L1 expression with CPS $>5 \%$ had concluded that only stromal PDL1 was prognostic in HPV-negative OPSCC [94]. However, none of these results support the notion that PD-L1 expression levels link to improved outcome in a consistent way.

\section{PD-L1 Expression to Stratify Treatment}

In the context of immune checkpoint inhibitor trials in HNSCC, IHC-assessed PDL1 expression was scored on either tumour cells alone (TPS) or also including tumourinfiltrating immune and stromal cells (CPS). For example, in CHECKMATE-141 [89,91], a PD-L1 tumour membrane expression of $\geq 1 \%$ expression was the positive definition using the Dako PD-L1 IHC 28-8 pharm Dx test. This concluded that there was a greater positive impact on outcome for nivolumab-treated patients compared to those receiving standard therapy if their tumours expressed PD-L1 and compared to those with PD-L1negative tumours. However, by 2 years of follow-up, checkpoint inhibitor treatment also showed evidence of benefit in the patients with PD-L1-"negative" tumours. Refining the definition of positivity for the PD-L1 expression scores of $\geq 1 \%$ vs. $\geq 5 \%$ vs. $\geq 10 \%$ showed increased overall response rates, but did not alter the OS measures [89]. Clearly, this biomarker methodology cannot identify all the patients that could respond to treatment. 
When the presence of PD-L1-expressing tumour-associated immune cells were included in the scoring, this was shown to be more predictive of benefit than tumour cell PD-L1 expression alone, but this was complicated by the observation that the predicted increased benefit from nivolumab compared to SOC was greater in tumour cell PD-L1-negative patients [91]. For KEYNOTE-040, PD-L1 tumour expression was assessed by a different test (Dako PD-L1 IHC 22C3 pharmDx). In exploratory analyses, not adjusted for multiplicity, an interaction between the treatment effect for OS and PD-L1 expression was seen, with the benefit of pembrolizumab greater in patients with a CPS $\geq 1$ compared to CPS $<1$; this was also seen when stratifying tumours by TPS $\geq 50 \%$ versus $<50 \%$. These preliminary results suggest benefits on PFS and objective response of checkpoint inhibitor versus SOC therapy which are greater in patients whose tumours had higher PD-L1 expression [90]. Further studies assessing PD-L1 positivity (CPS $\geq 1$ ) showed a significant improvement in OS compared to SOC $[3,96]$. These phase III studies in patients with R/M HNSCC for nivolumab (CHECKMATE-141) and pembrolizumab (KEYNOTE-040) compared to SOC led to FDA/EMA approval; the EMA subsequently restricted pembrolizumab to patients with tumours scoring TPS $\geq 50 \%$ [3].

In a further development, the KEYNOTE-048 study investigated the use of pembrolizumab as first-line treatment for platinum-sensitive patients with $\mathrm{R} / \mathrm{M}$ disease. This showed that compared to SOC, CT (platinum + 5-FU), pembrolizumab, plus CT provided a better OS in the PD-L1 CPS $\geq 20$, CPS $\geq 1$, and total populations, while pembrolizumab monotherapy demonstrated superior OS in the CPS $\geq 20$ and $\geq 1$ populations and was non-inferior in the total population [3,97]. The FDA has approved pembrolizumab for CPS $\geq 1$ patients and for pembrolizumab and CT for the entire population, but the EMA restricted its use to CPS $\geq 1$ patients receiving pembrolizumab alone or with CT. The 2-year survival rates of 29-35\% are significantly improved compared to the EXTREME regimen, notwithstanding the reduced toxicity. Response rates are still less than $23 \%$ with $40.5 \%$ progression for pembrolizumab alone, so there is still plenty to do to increase efficacy and focus such immunotherapy. Importantly, the response rate to pembrolizumab plus CT of $35 \%$ does not improve on that delivered by CT alone while the nearly doubled survival rate of $30 \%-35 \%$ is about the same as the immunotherapy alone [97].

Here, only some of the pivotal clinical trials have been described to highlight the issues of utilising biomarkers in immune checkpoint inhibitor treatment selection. There are more details of the evolution of these, and many other supporting studies in Borel et al. 2020 [88]. While there is a general correlation of PD-L1 tumour expression with immune checkpoint inhibitor efficacy in R/M HNSCC, with improved predictive quality when using CPS, it is still clear that some patients whose tumours area scored as PD-L1-negative can still benefit from treatment. Comparative studies of reagents and methodologies are being conducted, but so far without any definitive conclusions.

\section{General Reflections on Biomarkers for OPSCC}

It does appear that right now there is a limited value in IHC-based assessments of PD-L1 expression for accurately determining treatment options. The challenge is how to interpret measures (e.g., density) of different populations of immune and other cell types and their functional status from 2D snapshots accounting proximity and the presence of soluble factors that will be integrated to contribute to "responsiveness". Ultimately, multiplex IHC techniques will have a limit of simultaneously analysable markers even when utilising automated scanning and scoring systems. How likely is any combination of factors measured by such mainly IHC studies ever going to reflect the nuances of the multitude of components that are dynamically integrating to determine potential responsiveness to a checkpoint inhibitor in an OPSCC patient? Given the number of other known regulatory pathways active in the TME and systemically, plus undoubtedly unknown unknowns, the failure to identify a really specific measure of PD-L1 expression for very accurate prognostics and treatment deployment in HNSCC (OPSCC) is probably understandable. 
In other words, current biomarkers like those being investigated above do not provide a sufficiently granular distinction between one tumour and another to achieve effective stratification of treatment. It follows that until studies can be conducted with more "granular" eligibility (biomarker profile) for checkpoint therapy, it will be difficult to identify cohorts who can best benefit from this approach.

The analyses for PD-L1 so far have been based on a reasonable hypothesis whereby more PD-L1 expression in the tumour reflects a history of undermined immune control which is available to be released on checkpoint inhibition. Some have hypothesised and found general evidence supporting the idea that there is a correlation between the number of accumulated mutations, thereby generating potential tumour antigens, and the response to checkpoint inhibitors [98-101]. T cell infiltration in tumours is also well correlated with improved outcomes with Immunoscore providing useful prognostic information in colorectal cancer [36].

Future progress in determining better prognostic and therapy application tools may require the integration of additional classification features of a tumour incorporating the mutational load, (epi) genetic background (microsatellite instability) status, chromosomal instability, and $\mathrm{CpG}$ island methylator phenotype status, as well as risk factors like virus or other infection, UV, chemical, and physical carcinogen exposure [102]. Such investigations emphasize the importance of the immune context but also the extent of the positive and negative factors shaping carcinogenesis and tumour progression or control. A recent study has focused on the balance of PD-1 positive CD8+ T and Treg cells in cancers and shown that the ratio in the TME can predict the clinical efficacy of PD-1 blockade therapies compared to PD-L1 expression or mutational burden [103]. It is hypothesized that a better recovery of dysfunctional PD-1-positive CD8+ rather than Tregs is required for tumour regression. This once again highlights the relative lack of predictive power with such approaches.

The functionality of infiltrating $\mathrm{T}$ cells effectors induced by chronic stimulation, typically viral, can also lead to a state of exhaustion [104]. Such T cells over-express several inhibitory receptors (e.g., PD-1), exhibit major changes in T cell receptor and cytokine signalling pathways, have changes in expression of genes controlling chemotaxis, adhesion, and migration, and show distinct transcriptional signatures and various metabolic and bioenergetic deficiencies $[105,106]$. The continuous stimulation of naïve $\mathrm{T}$ cells in the local lymph node leads to a skewed population of CD8+ effectors at lesion sites with functional T cell exhaustion progressive but distinct from anergy [107]. A homeostatic mechanism is invoked that aims to protect the repertoire of antigen-specific $\mathrm{T}$ cells by generating a stem cell-like CD8+ non-recirculating population which resides in T cell zones of lymphoid tissues along with the naïve T cells [108]. They are quiescent but have proliferative potential and provide a means to sustain supply of activated specific $\mathrm{T}$ cells in a chronic situation. Tcf-1 is critical for generation of this PD-1-positive CD8+ T cell subset which can permit self-renewal as well as differentiate into more terminally differentiated cells that down-regulate Tcf- 1 and with a transitory population of CD101-negative Tim3-positive cells can convert to CD101-positive Tim-positive T effectors. Importantly, PD-1 pathway blockade increases the numbers of transitory cells, suggesting that these cells play a critical role in PD-1-based immunotherapy [106]. While these novel sets of both terminally differentiated and stem-like CD8+ T cells have mostly been investigated in chronic virus infection they have also been detected in human tumours. Importantly, they are found in pseudo-antigen-presenting-cell niches within some tumours and, interestingly, patients with progressive disease seem to lack these immune niches and this correlates with low levels of T cell infiltration $[109,110]$. It appears that the mechanisms underlying checkpoint blockade depend not on a simple reversal of $\mathrm{T}$ cell exhaustion but requires the expansion of the stem-like population [110-112]. When these cells are released from their quiescence, they are subsequently receptive to antigen presentation, and can mobilize, proliferate, and functionally differentiate. The checkpoint blockade may also influence effector function at the target sites with increased killing and cytokine release. A greater understanding of how to best mobilize this unique stem-like population in a chronic viral-driven tumour 
will be important to maximizing the impact of therapies which seek to harness the immune response [41].

Finally, using dissociated OPSCC tissues and more powerful techniques based on mass spectrometry and/or single-cell RNA analyses may provide for the use of more co-markers to improve precision in identifying particular populations like CD103+ tissue-resident $T$ cells whose presence and function may be pivotal in anti-tumour immunity [74,112-115]. However, the analyses may be compromised by the process of recovery altering the cellular RNA, etc. expression status. Nevertheless, such approaches could be useful in revealing important features of the TME critical to outcomes in response to available treatments. There are also platforms available which can integrate multiplexed expression data (RNA, protein) from particular individual cells in the context of the tissue with the option to look for dynamic changes seen in disease progression or treatment [116-118].

On the other hand, the practicality of these more sophisticated techniques to routine assessment for either prognostics or treatment allocation is more doubtful through logistic and cost issues, at least in the short term. This article has therefore concentrated on immune factors assessed locally in the context of checkpoint inhibitors as a central pivot in current therapeutic treatments in OPSCC. More global analyses of gene expression patterns have been applied to define different HNSCC subtypes incorporating biological characteristics and de-regulated signalling pathways as immunoreactive, inflammatory, HPV-like, classical, hypoxia-associated, and mesenchymal with the latter two more aggressive [103]. More information does not necessarily provide useful clinical insights if the subgroups are too numerous and still heterogeneous $[119,120]$.

\section{Types of Combination HNSCC (OPSCC) Therapies under Investigation}

In the context of checkpoint inhibitor treatments for HNSCC (OPSCC) there is established proof of principle for improved management which warrants continued research for useful biomarkers enabling better prognostics and treatment deployment. To a large extent, biomarker studies are mostly an add on, or evaluated post hoc, in clinical trials primarily investigating the efficacy of increasing numbers and varieties of immune checkpoint inhibitors delivered in combination with variations of SOC or with other experimental immuno-therapeutic strategies. It is sobering to consider that a fundamental re-evaluation of the influence of radiation and chemical treatment protocols on both local and systemic functional immunity should really be reconsidered in the context of the deployment of immunotherapies aimed at either recovery of an existing immune response or the induction of novel anti-tumour activity [121-123]. The ongoing clinical studies of checkpoint inhibitors in HNSCC have recently been reviewed by the van der Burg group [46] and can be comprehensively accessed at Clinicaltrials.gov [124]. The extent and diversity of approaches reveals a somewhat scatter-gun approach which may luck out but could also just consume resources for a minimal gain. A summary of a selection of ongoing later phase $2 / 3$ trials outlining the design, size, patient eligibility criteria, primary endpoints, and their timelines is given Table 3. These relatively few examples illustrate the challenges of designing meaningful clinical studies to investigate PD-1/PD-L1 pathway inhibition in the context of suboptimal SOC with a view to improved patient management/outcomes. Is it the case that this activity is only likely to further progress incrementally for highly defined groups and that for the majority of patients real progress will require new treatment paradigms based on new knowledge? 
Table 3. Selected phase $2 / 3$ clinical trials involving immune PD-1/PD-L1 pathway inhibitors in HNSCC(OPSCC).

\begin{tabular}{|c|c|c|c|c|c|}
\hline NCT (ClinicalTrials.Gov) & Design & Treatment Arms & Patient Eligibility & Primary Endpoints & Start (Month/Year) Status \\
\hline 03082534 & $\begin{array}{l}\text { Open-label, non-randomized, } \\
\text { multi-arm phase II trial of } \\
\text { pembrolizumab combined with } \\
\text { cetuximab for patients with R/M } \\
\text { HNSCC }\end{array}$ & $\begin{array}{c}\text { Treatment: } \\
\text { Pembrolizumab/Cetuximab } \\
\text { Cohort 1 (PD-1/PD-L1 } \\
\text { inhibitor-naïve, } \\
\text { cetuximab-naïve); Cohort } 2 \\
\text { (PD-1/PD-L1 } \\
\text { inhibitor-refractory, } \\
\text { cetuximab-naïve); Cohort } 3 \\
\text { (PD-1/PD-L1 } \\
\text { inhibitor-refractory, } \\
\text { cetuximab-refractory); Cohort } \\
4 \text { (cutaneous HNSCC) }\end{array}$ & $\begin{array}{l}83 \text { HNSCC not amenable to } \\
\text { curative intent therapy. }\end{array}$ & $\begin{array}{l}\text { ORR at: } 6 \text { months } \\
\text { Proportion of patients with } \\
\text { partial or complete response } \\
\text { in tumour burden }\end{array}$ & $\begin{array}{l}3 / 2017 \\
\text { Active }\end{array}$ \\
\hline 01810913 & $\begin{array}{l}\text { Randomized phase II/III trial of } \\
\text { adjuvant RT with cisplatin, } \\
\text { docetaxel-cetuximab, or } \\
\text { cisplatin-Atezolizumab } \\
\text { (anti-PD-L1) in HR HNSCC. } \\
\text { First select the better } \\
\text { docetaxel-based exptl arm to DFS } \\
\text { over control arm 1. (Phase II) } \\
\text { (COMPLETE 3/2020) } \\
\text { To determine if combination of } \\
\text { docetaxel-cetuximab \& IMRT is } \\
\text { superior for OS compared to } \\
\text { standard cisplatin \& IMRT in } \\
\text { adjuvant treatment (Phase III) To } \\
\text { determine if combination of } \\
\text { atezolizumab, cisplatin, \& IMRT } \\
\text { is superior in terms of OS } \\
\text { compared to standard cisplatin \& } \\
\text { IMRT in the adjuvant treatment } \\
\text { HPV-negative HNSCC (Phase III) }\end{array}$ & $\begin{array}{c}\text { Experimental: Arm } 1 \text { (IMRT, } \\
\text { cisplatin) } \\
\text { Experimental: Arm } 2 \text { (IMRT, } \\
\text { docetaxel) } \\
\text { Experimental: Arm } 3 \text { (IMRT, } \\
\text { docetaxel, cetuximab) } \\
\text { Experimental: Arm } 4 \text { (IMRT, } \\
\text { cisplatin, atezolizumab) }\end{array}$ & 613 HPV negative HNSCC & $\begin{array}{l}\text { DFS (Phase II) up to } 7 \text { years } \\
\text { OS (Phase III) up to } 7 \text { years }\end{array}$ & $\begin{array}{l}3 / 2013 \\
\text { Active }\end{array}$ \\
\hline
\end{tabular}


Table 3. Cont.

Experimental: Low Risk

Part 1: 6 weeks of induction

carboplatin chemotherapy;

$$
\text { Part 2: 2-6 weeks }
$$

post-induction, tumour

imaging, \& surgical resection

Part 3: adjuvant durvalumab

Experimental: Medium Risk

Part 1: 6 weeks of induction carboplatin chemotherapy in

$$
\text { combination with }
$$

Multimodality therapy with

induction carboplatin/nab-

03174275

paclitaxel/durvalumab followed

by surgical resection \&$$
\text { durvalu }
$$

weeks post-induction,

tumour imaging \& surgical

resection; Part 3: ipsilateral

involved field radiation

concurrent with cisplatin

followed by durvalumab.

Experimental: High Risk

6 weeks of induction

carboplatin chemotherapy in

$$
\text { combination with }
$$

durvalumab; Part 2: 2-6

weeks post-induction,

tumour imaging \& surgical

resection; Part 3 IMRT

concurrent with cisplatin or

SOC \& then durvalumab
39 previously untreated,

histologically proven,

surgically resectable primary

HNSCC stage III or IV (HPV

or negative non-metastatic disease)
Pathologic CRR after

induction chemotherapy with

carboplatin, nab-paclitaxel, \&

durvalumab in previously

untreated stage III/IV

HNSCC amenable to surgical

resection approximately 8-12

weeks after start of study treatment
6/2017

Active 
Table 3. Cont

\begin{tabular}{|c|c|c|c|c|c|}
\hline NCT (ClinicalTrials.Gov) & Design & Treatment Arms & Patient Eligibility & Primary Endpoints & Start (Month/Year) Status \\
\hline 03258554 & $\begin{array}{l}\text { Randomized phase II/III trial of } \\
\text { radiotherapy with concurrent } \\
\text { durvalumab vs. radiotherapy } \\
\text { with concurrent cetuximab in LA } \\
\text { HNCCC patients with } \\
\text { contraindication to cisplatin }\end{array}$ & $\begin{array}{l}\text { Active Comparator Arm: } \\
\text { cetuximab, RT } \\
\text { Experimental Arm: } \\
\text { durvalumab, RT }\end{array}$ & $\begin{array}{c}474 \text { LA HNSCC } \\
\text { Not suitable for cisplatin } \\
\text { treatment }\end{array}$ & $\begin{array}{l}\text { DLT up to } 4 \text { weeks after RT } \\
\text { PFS (Phase II) up to } 3 \text { years } \\
\text { OS (Phase III) up to } 3 \text { years }\end{array}$ & $\begin{array}{l}\text { 8/2017 } \\
\text { Active }\end{array}$ \\
\hline 03383094 & $\begin{array}{l}\text { Phase II randomized trial of } \\
\text { radiotherapy with concurrent \& } \\
\text { adjuvant pembrolizumab versus } \\
\text { concurrent chemotherapy in } \\
\text { patients with } \\
\text { advanced/intermediate-risk p16+ } \\
\text { HNSCC }\end{array}$ & $\begin{array}{l}\text { Active Comparator: } \\
\text { Control-RT/cisplatin } \\
\text { Experimental: } \\
\text { RT/pembrolizumab }\end{array}$ & $\begin{array}{c}114 \mathrm{HNSCC} \mathrm{HPV}+(\mathrm{p} 16) \\
\text { high-intermediate risk } \\
\text { disease }\end{array}$ & PFS up to 3 years & $\begin{array}{c}\text { 12/2017 } \\
\text { Active }\end{array}$ \\
\hline 03410615 & $\begin{array}{l}\text { Non-comparative, randomized, } \\
\text { phase II study of cisplatin plus } \\
\text { radiotherapy or durvalumab plus } \\
\text { radiotherapy followed by } \\
\text { adjuvant durvalumab or } \\
\text { durvalumab plus radiotherapy } \\
\text { followed by adjuvant } \\
\text { tremelimumab and durvalumab } \\
\text { in LA HPV+ OPSCC }\end{array}$ & $\begin{array}{c}\text { Active Comparator: } \\
\text { Radiation/Cisplatin } \\
\text { Experimental: } \\
\text { Radiation/Durvalumab + } \\
\text { Adjuvant Durvalumab } \\
\text { Experimental: } \\
\text { Radiation/Durvalumab + } \\
\text { Adjuvant Durval- } \\
\text { umab/Tremelimumab (Arm } \\
\text { closed to accrual in 2019) }\end{array}$ & 180 LA HPV + (p16) HNSCC & 3 year event-free survival & $1 / 2018$ active \\
\hline 03468218 & $\begin{array}{l}\text { Studies effects of pembrolizumab } \\
\text { \& cabozantinib (protein kinase } \\
\text { inhibitor) in treating R/M } \\
\text { HNSCC. }\end{array}$ & $\begin{array}{l}\text { Experimental: Treatment } \\
\text { (pembrolizumab, } \\
\text { cabozantinib) }\end{array}$ & $53 \mathrm{HPV}+\mathrm{HNSCC}$ & ORR & $\begin{array}{c}3 / 2018 \\
\text { Active }\end{array}$ \\
\hline
\end{tabular}


Table 3. Cont

\begin{tabular}{|c|c|c|c|c|c|}
\hline NCT (ClinicalTrials.Gov) & Design & Treatment Arms & Patient Eligibility & Primary Endpoints & Start (Month/Year) Status \\
\hline 03618134 & $\begin{array}{c}\text { Studies the side effects \& how } \\
\text { well stereotactic body radiation } \\
\text { therapy \& durvalumab } \\
\text { (anti-PD-L1) with or without } \\
\text { tremelimumab (anti-CTLA4) } \\
\text { before surgery work in treating } \\
\text { participants with HPV+ OPSCC }\end{array}$ & $\begin{array}{c}\text { Experimental: Cohort I (SBRT, } \\
\text { durvalumab, TORS, neck } \\
\text { dissection) } \\
\text { Experimental: Cohort II } \\
\text { (SBRT, durvalumab, } \\
\text { tremelimumab, TORS, neck } \\
\text { dissection) }\end{array}$ & $\begin{array}{l}82 \mathrm{HPV}+(\mathrm{p} 16 \mathrm{IHC}) \text { OPSCC. } \\
\text { T0-3 disease with gross } \\
\text { disease amenable to R0 } \\
\text { resection (TORS eligible); } \\
\text { N0-N2b, disease confined to } 2 \\
\text { cervical LN levels if adjacent. }\end{array}$ & $\begin{array}{l}\text { Phase } 1 \text { safety-related } \\
\text { adverse events up to } 90 \text { days } \\
\text { PFS (Phase II from enrolment } \\
\text { to the first occurrence of } \\
\text { disease progression up to } 2 \\
\text { years \& AE incidence }\end{array}$ & $\begin{array}{l}8 / 2018 \\
\text { Active }\end{array}$ \\
\hline 03646461 & $\begin{array}{c}\text { Randomized, phase II testing } \\
\text { efficacy of Ibrutinib (tyrosine } \\
\text { kinase inhibitor) in combination } \\
\text { with either nivolumab or } \\
\text { Cetuximab (EGFR inhibitor) in } \\
\text { R/M HNSCC }\end{array}$ & $\begin{array}{l}\text { Arm A: Ibrutinib + } \\
\text { Cetuximab } \\
\text { Arm B: Ibrutinib + } \\
\text { Nivolumab }\end{array}$ & $\begin{array}{l}39 \mathrm{R} / \mathrm{M} \text { HNSCC not yet } \\
\text { treated with EGFR inhibitors }\end{array}$ & $\begin{array}{l}\text { Efficacy of Combined } \\
\text { Therapies at } 3 \text { years }\end{array}$ & $\begin{array}{l}8 / 2018 \\
\text { Active }\end{array}$ \\
\hline 03669718 & $\begin{array}{c}\text { A blinded, placebo-controlled, } \\
\text { randomized, phase } 2 \text { study in } \\
\text { which subjects will be randomly } \\
\text { assigned 1:1 to cemiplimab plus } \\
\text { placebo or cemiplimab plus } \\
\text { ISA101b. }\end{array}$ & $\begin{array}{c}\text { Experimental: Active } \\
\text { ISA101b \& cemiplimab } \\
\text { Placebo Comparator: Placebo } \\
\text { and cemiplimab }\end{array}$ & $\begin{array}{l}\text { 194 R/M OPSCC HPV16 +, } \\
\text { PD-L1+ (CPS } \geq 1 \text { ). Patients } \\
\text { suitable for first-line PD-1 } \\
\text { blocking antibody \& with } \\
\text { disease progression on or } \\
\text { after platinum containing } \\
\text { chemotherapy. }\end{array}$ & $\begin{array}{l}\text { ORR \& treatment-related } \\
\text { adverse events in } 25 \text { months }\end{array}$ & $\begin{array}{l}9 / 2018 \\
\text { Active }\end{array}$ \\
\hline 03799445 & $\begin{array}{l}\text { Studies side effects \& best dose of } \\
\text { ipilimumab (anti-CTLA4), } \\
\text { nivolumab, radiation therapy in } \\
\text { HPV+ OPSCC patients }\end{array}$ & $\begin{array}{l}\text { Single Arm: Nivolumab, } \\
\text { ipilimumab, IMRT }\end{array}$ & $\begin{array}{c}180 \text { stage } 1-\mathrm{II} \\
(\mathrm{p} 16+, \mathrm{HPV} \text { DNA or RNA+) }\end{array}$ & $\begin{array}{c}\text { DLTs relating } \\
\text { immunotherapy. For phase II: } \\
\text { CRR (at } 6 \text { months \& PFS at } 2 \\
\text { years) }\end{array}$ & $\begin{array}{l}1 / 2019 \\
\text { Active }\end{array}$ \\
\hline 03829722 & $\begin{array}{l}\text { Does } 2 \text { yr PFS improve with add } \\
\text { of nivolumab compared to SOC } \\
\text { fractionated RT \& } \\
\text { carboplatin/paclitaxel? }\end{array}$ & $\begin{array}{l}\text { Single Arm: Nivolumab, } \\
\text { Carboplatin/Paclitaxel, } \\
\text { Radiotherapy }\end{array}$ & 40 stage $3(\mathrm{p} 16+)$ OPSCC & PFS up to 2 years & $\begin{array}{l}2 / 2019 \\
\text { Active }\end{array}$ \\
\hline 03952585 & $\begin{array}{l}\text { Does a reduced dose of radiation } \\
\text { therapy \& nivolumab (anti-PD-1) } \\
\text { work as well as standard dose } \\
\text { radiation therapy \& cisplatin } \\
\text { OPSCC patients? }\end{array}$ & $\begin{array}{c}\text { Arm I: IMRT, IGRT, cisplatin } \\
\text { Arm 2: Reduced IMRT, IGRT, } \\
\text { cisplatin } \\
\text { Arm 3: IMRT, IGRT, } \\
\text { nivolumab }\end{array}$ & 711 stage 1-II (p16+) OPSCC & $\begin{array}{c}\text { PFS (Phase II/III) up to } 6 \\
\text { years; QOL }\end{array}$ & $\begin{array}{l}5 / 2019 \\
\text { Active }\end{array}$ \\
\hline
\end{tabular}


Table 3. Cont.

\begin{tabular}{|c|c|c|c|c|c|}
\hline NCT (ClinicalTrials.Gov) & Design & Treatment Arms & Patient Eligibility & Primary Endpoints & Start (Month/Year) Status \\
\hline 03978689 & $\begin{array}{l}\text { Phase } 1 \text { dose escalation \& } \\
\text { expansion study evaluating the } \\
\text { safety, anti-tumour effect, \& } \\
\text { immunogenicity of CUE-101 as } \\
\text { monotherapy treatment in } \\
\text { 2ndline or CUE-101 combination } \\
\text { therapy with pembrolizumab in } \\
\text { first-line HPV16+ R/M (HNSCC) } \\
\text { patients. CUE-101 is a novel } \\
\text { fusion protein designed to } \\
\text { activate \& expand a population } \\
\text { of tumour-specific T cells to } \\
\text { eradicate HPV-driven } \\
\text { malignancies }\end{array}$ & $\begin{array}{l}\text { Part A\&B: First-in-human } \\
\text { trial, to assess safety \& } \\
\text { tolerability of CUE-101 in } \\
\text { subjects with R/M HNSCC in } \\
2^{\text {nd }} \text {-line setting, to determine } \\
\text { MTD or recommend Phase } 2 \\
\text { dose based on markers of } \\
\text { biological activity. PK, } \\
\text { anti-tumour immune } \\
\text { response, preliminary } \\
\text { anti-tumour activity \& } \\
\text { immunogenicity will also be } \\
\text { assessed. } \\
\text { Part C\&D: Characterize } \\
\text { safety, tolerability, \& } \\
\text { biological effects of CUE-101 } \\
\text { in combination with } \\
\text { pembrolizumab in R/M } \\
\text { HNSCC patients in first-line } \\
\text { setting. }\end{array}$ & $\begin{array}{l}85 \text { patients, HPV } 16+(\mathrm{RNA} \\
\text { ISH \& p16 IHC) R/M } \\
\text { HNSCC progressed following } \\
\text { at least } 1 \text { prior systemic } \\
\text { therapy. } \\
\text { HLA A }{ }^{*} 0201 \text { genotype }\end{array}$ & $\begin{array}{l}\text { The primary objectives of the } \\
\text { Part A\&B, first-in-human } \\
\text { trial, are to assess the safety } \\
\text { and tolerability of CUE-101 in } \\
\text { subjects with } \\
\text { recurrent/metastatic HNSCC } \\
\text { in the second-line setting and } \\
\text { to determine the maximum } \\
\text { tolerated dose or } \\
\text { recommended Phase } 2 \text { dose } \\
\text { based on markers of } \\
\text { biological activity }\end{array}$ & $\begin{array}{l}6 / 2019 \\
\text { Active }\end{array}$ \\
\hline 04398524 & $\begin{array}{l}\text { Testing ISA101b (HPV 16 E6/E7 } \\
\text { synethetic long peptide vaccine) } \\
\text { plus cemiplimab in subjects who } \\
\text { have progressed on prior } \\
\text { anti-PD-1 therapy }\end{array}$ & $\begin{array}{l}\text { Single arm: ISA101b } 3 \text { times } \\
\text { plus cemiplimab every } 3 \\
\text { weeks for up to } 24 \text { months }\end{array}$ & $\begin{array}{l}\text { 86 PD metastatic HPV16 + } \\
\text { OPSCC at primary site \& LNs } \\
\text { limited to neck. Patients had } \\
\text { at least } 4 \text { doses anti-PD-1 } \\
\text { antibody with or without } \\
\text { chemotherapy within } 6 \\
\text { months. }\end{array}$ & $\begin{array}{l}\text { Improvement in ORR after } \\
\text { previous progression }\end{array}$ & $\begin{array}{l}5 / 2020 \\
\text { Active }\end{array}$ \\
\hline
\end{tabular}


Table 3. Cont.

\begin{tabular}{|c|c|c|c|c|c|}
\hline NCT (ClinicalTrials.Gov) & Design & Treatment Arms & Patient Eligibility & Primary Endpoints & Start (Month/Year) Status \\
\hline 04634825 & $\begin{array}{c}\text { Study of enoblituzumab } \\
\text { (anti-B7-H3 targets B7 family } \\
\text { immune regulatory molecule) } \\
\text { combined with either } \\
\text { retifanlimab (anti-PD-1) or } \\
\text { tebotelimab (bispecific DART } \\
\text { molecule designed to } \\
\text { independently or coordinately } \\
\text { block PD-1 \& LAG-3 checkpoint } \\
\text { molecules) given as first-line } \\
\text { treatment to patients with R/M } \\
\text { HNSCC }\end{array}$ & $\begin{array}{c}\text { Arm 1: retifanlimab cohort } \\
\text { (Enoblituzumab }+ \\
\text { retifanlimab) } \\
\text { Arm 2: tebotelimab cohort } \\
\text { Enoblituzumab + tebotelimab }\end{array}$ & $\begin{array}{c}80 \mathrm{R} / \mathrm{M} \text { HNSCC } 50 \\
\text { PD-L1+ve in retifanlimab } \\
\text { cohort } \\
30 \text { PD-L1-ve in } \\
\text { tebotelimabcohort. }\end{array}$ & $\begin{array}{l}\text { Efficacy of enoblituzumab } \\
\text { plus retifanlimab or } \\
\text { enoblituzumab plus } \\
\text { tebotelimab at } 28 \text { months } \\
\text { Safety by } 30 \text { days after last } \\
\text { dose. Incidence of } \\
\text { treatment-emergent adverse } \\
\text { events }\end{array}$ & $\begin{array}{l}11 / 2020 \\
\text { Active }\end{array}$ \\
\hline 04671667 & $\begin{array}{l}\text { Studies effect of pembrolizumab } \\
\text { in combination with radiation } \\
\text { therapy or pembrolizumab alone } \\
\text { or SOC (chemotherapy plus } \\
\text { radiation) in R/M HNSCC after } \\
\text { surgery }\end{array}$ & $\begin{array}{c}\text { Arm A: pembrolizumab, } \\
\text { IMRT, PBRT } \\
\text { Arm B: cisplatin, carboplatin, } \\
\text { IMRT, PBRT } \\
\text { Arm C: pembrolizumab }\end{array}$ & $\begin{array}{l}\mathrm{R} / \mathrm{M} \text { HNSCC in a previously } \\
\text { radiated field after surgery. } \\
\text { HR disease with tumour } \\
\text { PD-L1 (CPS) } \geq 1\end{array}$ & $\begin{array}{l}\text { OS at } 2 \text { years } \\
\text { Adverse events up to } 5 \text { years }\end{array}$ & $\begin{array}{l}12 / 2020 \\
\text { Active }\end{array}$ \\
\hline
\end{tabular}


Table 3. Cont.

\begin{tabular}{|c|c|c|c|c|c|}
\hline NCT (ClinicalTrials.Gov) & Design & Treatment Arms & Patient Eligibility & Primary Endpoints & Start (Month/Year) Status \\
\hline 04862650 & $\begin{array}{c}\text { Studies effect of cemiplimab } \\
\text { (anti-PD-1) in combination with } \\
\text { low-dose paclitaxel \& carboplatin } \\
\text { in R/M HNSCC }\end{array}$ & $\begin{array}{l}\text { Single Arm: cemiplimab, } \\
\text { paclitaxel, carboplatin) }\end{array}$ & 33 R/M HNSCC & ORR at 12 weeks & NYA \\
\hline 04858269 & $\begin{array}{l}\text { Effects of carboplatin \& paclitaxel } \\
\text { plus pembrolizumab (anti-PD-1) } \\
\text { in HNSCC patients unable to } \\
\text { take 5FU }\end{array}$ & $\begin{array}{l}\text { Single Arm: Pembrolizumab } \\
\text { + carboplatin + paclitaxel in } \\
\text { outpatient setting }\end{array}$ & $\begin{array}{l}35 \mathrm{R} / \mathrm{M} \text { HNSCC not suitable } \\
\text { for infusional 5FU }\end{array}$ & $\begin{array}{l}\text { Do } 6 \text { cycles of } \\
\text { pembrolizumab with weekly } \\
\text { carboplatin/paclitaxel } \\
\text { increase the radiographic } \\
\text { response rate compared to } \\
\text { historical rate for } \\
\text { pembrolizumab alone? }\end{array}$ & NYA \\
\hline
\end{tabular}

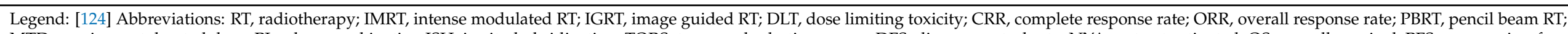

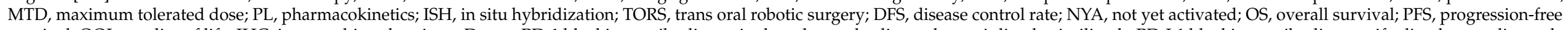

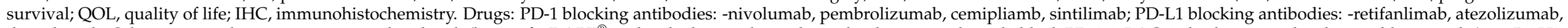

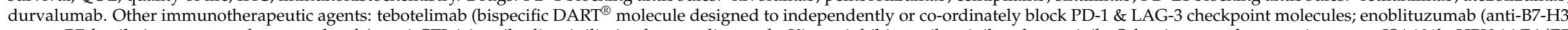

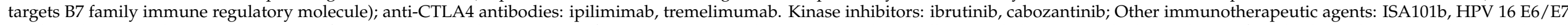

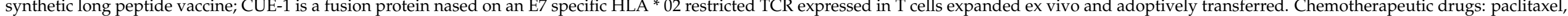
carboplatin, cisplatin, and docetaxel. 


\section{Final Reflections}

Many drugs targeting costimulatory and coinhibitory immune checkpoint molecules have now been developed. How conventional therapy influences these pathways in different immune cell subsets and beyond during the course of treatment is largely unknown. Some recent studies have begun to investigate such effects and may help to identify possible novel combinational therapeutic approaches $[125,126]$. The caveat is that these regulatory networks are often interactive (cellular and extracellular) and provide a redundancy that allows for fine tuning in responses, so insight from only a few biomarker assessments may be relatively limited. Combination treatments based on understanding the influence of immune deviation on tumour survival have utilised initial chemotherapy to provide for a reduction in the levels of MDSCC followed by HPV 16 oncogene vaccination which is then more effective at stimulating anti-tumour $\mathrm{T}$ cell responses, enabling prolonged survival $[127,128]$. Likewise, checkpoint blockade in combination with tumor-specific vaccination of patients with HPV16-related cancer has been attempted and has shown some promise [129]. Going forward, especially by utilising technology advances, additional modification strategies will be investigated to improve targeting and stimulation of cytotoxic $\mathrm{T}$ cell-based immune responses for optimal development of combination therapies [130,131].

A useful biomarker must identify a reasonable proportion of the patients where assignment of the associated treatment option has a high certainty of clinical value and where others are not excluded from this potential benefit. Ultimately, protocols which provide the best options for maximising response and minimising toxicity for the largest number of patients to be effectively treated are empirically determined in iterative clinical studies. The more factors used to refine the options for therapy selection, the more stratification of the patients occurs, ultimately leading to individually personalized medicine which must drive up costs even if logistically deliverable. Hopefully, the extensive testing of combinations of therapeutic approaches by types and sequencing will fuel the next evolution of treatment for OPSCC (HNSCC), albeit through the stalwarts of much medical progress, empiricism, and serendipity.

Author Contributions: Conceptualization, P.L.S. and T.D.; writing-original draft preparation, P.L.S. with assistance of T.D.; writing-review and editing, T.D. and P.L.S.; supervision, T.D. and P.L.S. All authors have read and agreed to the published version of the manuscript.

Funding: This research was funded by the Swedish Cancer Foundation (grant no. 20-0704).

Institutional Review Board Statement: Not applicable.

Informed Consent Statement: Not applicable.

Data Availability Statement: Not applicable.

Acknowledgments: We would like to thank Henry Kitchener for carefully reading this manuscript and for his valuable comments.

Conflicts of Interest: The authors declare no conflict of interest.

\section{References}

1. Cohen, N.; Fedewa, S.; Chen, A.Y. Epidemiology and Demographics of the Head and Neck Cancer Population. Oral Maxillofac. Surg. Clin. 2018, 30, 381-395. [CrossRef] [PubMed]

2. Johnson, D.E.; Burtness, B.; Leemans, C.R.; Lui, V.W.Y.; Bauman, J.E.; Grandis, J.R. Head and neck squamous cell carcinoma. Nat. Rev. Dis. Prim. 2020, 6, 1-22. [CrossRef]

3. Cohen, E.E.W.; Bell, R.B.; Bifulco, C.B.; Burtness, B.; Gillison, M.L.; Harrington, K.J.; Le, Q.T.; Lee, N.Y.; Leidner, R.; Lewis, R.L.; et al. The Society for Immunotherapy of Cancer consensus statement on immunotherapy for the treatment of squamous cell carcinoma of the head and neck (HNSCC). J. Immunother. Cancer 2019, 7, 184. [CrossRef] [PubMed]

4. Kang, H.; Kiess, A.; Chung, C.H. Emerging biomarkers in head and neck cancer in the era of genomics. Nat. Rev. Clin. Oncol. 2015, 12, 11-26. [CrossRef] [PubMed]

5. Bray, F.; Ferlay, J.; Soerjomataram, I.; Siegel, R.L.; Torre, L.A.; Jemal, A. Global cancer statistics 2018: GLOBOCAN estimates of incidence and mortality worldwide for 36 cancers in 185 countries. CA Cancer J. Clin. 2018, 68, 394-424. [CrossRef] [PubMed] 
6. Leemans, C.R.; Snijders, P.J.F.; Brakenhoff, R.H. The molecular landscape of head and neck cancer. Nat. Rev. Cancer 2018, 18, 269-282. [CrossRef]

7. Gillison, M.L.; Chaturvedi, A.K.; Anderson, W.F.; Fakhry, C. Epidemiology of Human Papillomavirus-Positive Head and Neck Squamous Cell Carcinoma. J. Clin. Oncol. 2015, 33, 3235-3242. [CrossRef]

8. Haeggblom, L.; Attoff, T.; Yu, J.; Holzhauser, S.; Vlastos, A.; Mirzae, L.; Ährlund-Richter, A.; Munck-Wikland, E.; Marklund, L.; Hammarstedt-Nordenvall, L.; et al. Changes in incidence and prevalence of human papillomavirus in tonsillar and base of tongue cancer during 2000-2016 in the Stockholm region and Sweden. Head Neck 2019, 41, 1583-1590. [CrossRef]

9. Simoens, C.; Gorbaslieva, I.; Gheit, T.; Holzinger, D.; Lucas, E.; Ridder, R.; Rehm, S.; Vermeulen, P.; Lammens, M.; Vanderveken, O.M.; et al. HPV DNA genotyping, HPV E6 ${ }^{*}$ I mRNA detection, and p16 ${ }^{\text {INK4a }} / \mathrm{Ki}-67$ staining in Belgian head and neck cancer patient specimens, collected within the HPV-AHEAD study. Cancer Epidemiol. 2021, 72, 101925. [CrossRef]

10. Huang, S.H.; O'Sullivan, B. Overview of the 8th Edition TNM Classification for Head and Neck Cancer. Curr. Treat. Options Oncol. 2017, 18, 40. [CrossRef]

11. Zanoni, D.K.; Patel, S.G.; Shah, J.P. Changes in the 8th Edition of the American Joint Committee on Cancer (AJCC) Staging of Head and Neck Cancer: Rationale and Implications. Curr. Oncol. Rep. 2019, 21, 1-7. [CrossRef]

12. El-Naggar, A.K.; Westra, W.H. p16 expression as a surrogate marker for HPV-related oropharyngeal carcinoma: A guide for interpretative relevance and consistency. Head Neck 2012, 34, 459-461. [CrossRef]

13. Wagner, S.; Prigge, E.S.; Wuerdemann, N.; Reder, H.; Bushnak, A.; Sharma, S.J.; Obermueller, T.; von Knebel Doeberitz, M.; Dreyer, T.; Gattenlöhner, S.; et al. Evaluation of $\mathrm{p} 16^{\mathrm{INK} 4 \mathrm{a}}$ expression as a single marker to select patients with HPV-driven oropharyngeal cancers for treatment de-escalation. Br. J. Cancer 2020, 123, 1114-1122. [CrossRef]

14. Schiffman, M.; Castle, P.E.; Jeronimo, J.; Rodriguez, A.C.; Wacholder, S. Human papillomavirus and cervical cancer. Lancet 2007, 370, 890-907. [CrossRef]

15. Doorbar, J.; Egawa, N.; Griffin, H.; Kranjec, C.; Murakami, I. Human papillomavirus molecular biology and disease association. Rev. Med. Virol. 2015, 25, 2-23. [CrossRef]

16. Litwin, T.R.; Clarke, M.A.; Dean, M.; Wentzensen, N. Somatic Host Cell Alterations in HPV Carcinogenesis. Viruses 2017, 9, 206. [CrossRef]

17. Doorbar, J.; Griffin, H. Refining our understanding of cervical neoplasia and its cellular origins. Papillomavirus Res. 2019, 7, 176-179. [CrossRef]

18. Sewell, A.; Brown, B.; Biktasova, A.; Mills, G.B.; Lu, Y.; Tyson, D.R.; Issaeva, N.; Yarbrough, W.G. Reverse-phase protein array profiling of oropharyngeal cancer and significance of PIK3CA mutations in HPV-associated head and neck cancer. Clin. Cancer Res. 2014, 20, 2300-2311. [CrossRef]

19. Bader, A.G.; Kang, S.; Zhao, L.; Vogt, P.K. Oncogenic PI3K deregulates transcription and translation. Nat. Rev. Cancer 2005, 5, 921-929. [CrossRef]

20. Zhang, Y.; Koneva, L.A.; Virani, S.; Arthur, A.E.; Virani, A.; Hall, P.B.; Warden, C.D.; Carey, T.E.; Chepeha, D.B.; Prince, M.E.; et al. Subtypes of HPV-Positive Head and Neck Cancers Are Associated with HPV Characteristics, Copy Number Alterations, PIK3CA Mutation, and Pathway Signatures. Clin. Cancer Res. 2016, 22, 4735-4745. [CrossRef]

21. Roselló, À.; Albuquerque, R.; Roselló-Llabrés, X.; Marí-Roig, A.; Estrugo-Devesa, A.; López-López, J. Transoral robotic surgery vs open surgery in head and neck cancer. A systematic review of the literature. Med. Oral Patol. Oral Cir. Bucal. 2020, 25, e599-e607. [CrossRef]

22. Lala, M.; Chirovsky, D.; Cheng, J.D.; Mayawala, K. Clinical outcomes with therapies for previously treated recurrent/metastatic head-and-neck squamous cell carcinoma (R/M HNSCC): A systematic literature review. Oral Oncol. 2018, 84, 108-120. [CrossRef]

23. Economopoulou, P.; De Bree, R.; Kotsantis, I.; Psyrri, A. Diagnostic Tumor Markers in Head and Neck Squamous Cell Carcinoma (HNSCC) in the Clinical Setting. Front. Oncol. 2019, 9, 827. [CrossRef]

24. Bossi, P.; Miceli, R.; Benasso, M.; Corvò, R.; Bacigalupo, A.; Sanguineti, G.; Fallai, C.; Merlano, M.C.; Infante, G.; Dani, C.; et al. Impact of treatment expertise on the outcome of patients with head and neck cancer treated within 6 randomized trials. Head Neck 2018, 40, 2648-2656. [CrossRef]

25. Szturz, P.; Wouters, K.; Kiyota, N.; Tahara, M.; Prabhash, K.; Noronha, V.; Castro, A.; Licitra, L.; Adelstein, D.; Vermorken, J.B. Weekly Low-Dose Versus Three-Weekly High-Dose Cisplatin for Concurrent Chemoradiation in Locoregionally Advanced Non-Nasopharyngeal Head and Neck Cancer: A Systematic Review and Meta-Analysis of Aggregate Data. Oncologist 2017, 22, 1056-1066. [CrossRef]

26. Vermorken, J.B.; Mesia, R.; Rivera, F.; Remenar, E.; Kawecki, A.; Rottey, S.; Erfan, J.; Zabolotnyy, D.; Kienzer, H.R.; Cupissol, D.; et al. Platinum-based chemotherapy plus cetuximab in head and neck cancer. N. Engl. J. Med. 2008, 359, 1116-1127. [CrossRef]

27. Iocca, O.; Farcomeni, A.; Di Rocco, A.; Di Maio, P.; Golusinski, P.; Pardiñas López, S.; Savo, A.; Pellini, R.; Spriano, G. Locally advanced squamous cell carcinoma of the head and neck: A systematic review and Bayesian network meta-analysis of the currently available treatment options. Oral Oncol. 2018, 80, 40-51. [CrossRef]

28. Pan, C.; Issaeva, N.; Yarbrough, W.G. HPV-driven oropharyngeal cancer: Current knowledge of molecular biology and mechanisms of carcinogenesis. Cancers Head Neck 2018, 3, 1-11. [CrossRef]

29. Pignon, J.P.; Le Maître, A.; Maillard, E.; Bourhis, J.; MACH-NC Collaborative Group. Meta-analysis of chemotherapy in head and neck cancer (MACH-NC): An update on 93 randomised trials and 17,346 patients. Radiother. Oncol. 2009, 92, 4-14. [CrossRef] [PubMed] 
30. Marur, S.; Li, S.; Cmelak, A.J.; Gillison, M.L.; Zhao, W.J.; Ferris, R.L.; Westra, W.H.; Gilbert, J.; Bauman, J.E.; Wagner, L.I.; et al. E1308: Phase II Trial of Induction Chemotherapy Followed by Reduced-Dose Radiation and Weekly Cetuximab in Patients With HPV-Associated Resectable Squamous Cell Carcinoma of the Oropharynx- ECOG-ACRIN Cancer Research Group. J. Clin. Oncol. 2017, 35, 490-497. [CrossRef]

31. Chen, A.M.; Felix, C.; Wang, P.C.; Hsu, S.; Basehart, V.; Garst, J.; Beron, P.; Wong, D.; Rosove, M.H.; Rao, S.; et al. Reduced-dose radiotherapy for human papillomavirus-associated squamous-cell carcinoma of the oropharynx: A single-arm, phase 2 study. Lancet Oncol. 2017, 18, 803-811. [CrossRef]

32. Gillison, M.L.; Trotti, A.M.; Harris, J.; Eisbruch, A.; Harari, P.M.; Adelstein, D.J.; Jordan, R.C.K.; Zhao, W.; Sturgis, E.M.; Burtness, B.; et al. Radiotherapy plus cetuximab or cisplatin in human papillomavirus-positive oropharyngeal cancer (NRG Oncology RTOG 1016): A randomised, multicentre, non-inferiority trial. Lancet 2019, 393, 40-50. [CrossRef]

33. Bonner, J.A.; Harari, P.M.; Giralt, J.; Cohen, R.B.; Jones, C.U.; Sur, R.K.; Raben, D.; Baselga, J.; Spencer, S.A.; Zhu, J.; et al. Radiotherapy plus cetuximab for locoregionally advanced head and neck cancer: 5-year survival data from a phase 3 randomised trial, and relation between cetuximab-induced rash and survival. Lancet Oncol. 2010, 11, 21-28. [CrossRef]

34. Ang, K.K.; Harris, J.; Wheeler, R.; Weber, R.; Rosenthal, D.I.; Nguyen-Tân, P.F.; Westra, W.H.; Chung, C.H.; Jordan, R.C.; Lu, C.; et al. Human papillomavirus and survival of patients with oropharyngeal cancer. N. Engl. J. Med. 2010, 363, 24-35. [CrossRef]

35. Kimple, R.J.; Smith, M.A.; Blitzer, G.C.; Torres, A.D.; Martin, J.A.; Yang, R.Z.; Peet, C.R.; Lorenz, L.D.; Nickel, K.P.; Klingelhutz, A.J.; et al. Enhanced radiation sensitivity in HPV-positive head and neck cancer. Cancer Res. 2013, 73, 4791-4800. [CrossRef]

36. Galon, J.; Mlecnik, B.; Bindea, G.; Angell, H.K.; Berger, A.; Lagorce, C.; Lugli, A.; Zlobec, I.; Hartmann, A.; Bifulco, C.; et al. Towards the introduction of the 'Immunoscore' in the classification of malignant tumours. J. Pathol. 2014, 232, 199-209. [CrossRef]

37. Mlecnik, B.; Van den Eynde, M.; Bindea, G.; Church, S.E.; Vasaturo, A.; Fredriksen, T.; Lafontaine, L.; Haicheur, N.; Marliot, F.; Debetancourt, D.; et al. Comprehensive Intrametastatic Immune Quantification and Major Impact of Immunoscore on Survival. J. Natl. Cancer Inst. 2018, 110, 97-108. [CrossRef]

38. Pan, C.; Liu, H.; Robins, E.; Song, W.; Liu, D.; Li, Z.; Zheng, L. Next-generation immuno-oncology agents: Current momentum shifts in cancer immunotherapy. J. Hematol. Oncol. 2020, 13, 1-15. [CrossRef]

39. Van Elsas, M.J.; Van Hall, T.; Van Der Burg, S.H. Future Challenges in Cancer Resistance to Immunotherapy. Cancers 2020, 12, 935. [CrossRef]

40. Smola, S.; Trimble, C.; Stern, P.L. Human papillomavirus-driven immune deviation: Challenge and novel opportunity for immunotherapy. Ther. Adv. Vaccines 2017, 5, 69-82. [CrossRef]

41. Stern, P.L. Harnessing immunity for therapy in human papillomavirus driven cancers. Tumour Virus Res. 2021, 11, 200212. [CrossRef]

42. Heeren, A.M.; De Boer, E.; Bleeker, M.C.; Musters, R.J.; Buist, M.R.; Kenter, G.G.; De Gruijl, T.D.; Jordanova, E.S. Nodal metastasis in cervical cancer occurs in clearly delineated fields of immune suppression in the pelvic lymph catchment area. Oncotarget 2015, 6, 32484-32493. [CrossRef]

43. Solomon, B.; Young, R.J.; Rischin, D. Head and neck squamous cell carcinoma: Genomics and emerging biomarkers for immunomodulatory cancer treatments. Semin. Cancer Biol. 2018, 52, 228-240. [CrossRef]

44. Wang, H.C.; Chan, L.P.; Cho, S.F. Targeting the Immune Microenvironment in the Treatment of Head and Neck Squamous Cell Carcinoma. Front. Oncol. 2019, 9, 1084. [CrossRef]

45. Wang, H.F.; Wang, S.S.; Tang, Y.J.; Chen, Y.; Zheng, M.; Tang, Y.L.; Liang, X.H. The Double-Edged Sword-How Human Papillomaviruses Interact With Immunity in Head and Neck Cancer. Front. Immunol. 2019, 10, 653. [CrossRef]

46. Welters, M.J.P.; Santegoets, S.J.; Van der Burg, S.H. The Tumor Microenvironment and Immunotherapy of Oropharyngeal Squamous Cell Carcinoma. Front. Oncol. 2020, 10. [CrossRef]

47. Oguejiofor, K.; Hall, J.; Slater, C.; Betts, G.; Hall, G.; Slevin, N.; Dovedi, S.; Stern, P.L.; West, C.M. Stromal infiltration of CD8 T cells is associated with improved clinical outcome in HPV-positive oropharyngeal squamous carcinoma. Br. J. Cancer 2015, 113, 886-893. [CrossRef]

48. Näsman, A.; Romanitan, M.; Nordfors, C.; Grün, N.; Johansson, H.; Hammarstedt, L.; Marklund, L.; Munck-Wikland, E.; Dalianis, T.; Ramqvist, T. Tumor infiltrating CD8+ and Foxp3+ lymphocytes correlate to clinical outcome and human papillomavirus (HPV) status in tonsillar cancer. PLoS ONE 2012, 7, e38711. [CrossRef]

49. Nordfors, C.; Grün, N.; Tertipis, N.; Ährlund-Richter, A.; Haeggblom, L.; Sivars, L.; Du, J.; Nyberg, T.; Marklund, L.; MunckWikland, E.; et al. CD8+ and CD4+ tumour infiltrating lymphocytes in relation to human papillomavirus status and clinical outcome in tonsillar and base of tongue squamous cell carcinoma. Eur. J. Cancer 2013, 49, 2522-2530. [CrossRef]

50. Ward, M.J.; Thirdborough, S.M.; Mellows, T.; Riley, C.; Harris, S.; Suchak, K.; Webb, A.; Hampton, C.; Patel, N.N.; Randall, C.J.; et al. Tumour-infiltrating lymphocytes predict for outcome in HPV-positive oropharyngeal cancer. Br. J. Cancer 2014, 110, 489-500. [CrossRef]

51. Wansom, D.; Light, E.; Thomas, D.; Worden, F.; Prince, M.; Urba, S.; Chepeha, D.; Kumar, B.; Cordell, K.; Eisbruch, A.; et al. Infiltrating lymphocytes and human papillomavirus-16-Associated oropharyngeal cancer. Laryngoscope 2012, 122, 121-127. [CrossRef]

52. Balermpas, P.; Michel, Y.; Wagenblast, J.; Seitz, O.; Weiss, C.; Rödel, F.; Rödel, C.; Fokas, E. Tumour-infiltrating lymphocytes predict response to definitive chemoradiotherapy in head and neck cancer. Br. J. Cancer 2014, 110, 501-509. [CrossRef]

53. Morrow, M.P.; Kraynyak, K.A.; Sylvester, A.J.; Dallas, M.; Knoblock, D.; Boyer, J.D.; Yan, J.; Vang, R.; Khan, A.S.; Humeau, L.; et al. Clinical and Immunologic Biomarkers for Histologic Regression of High-Grade Cervical Dysplasia and Clearance of HPV16 and HPV18 after Immunotherapy. Clin. Cancer Res. 2018, 24, 276-294. [CrossRef] 
54. Kobayashi, A.; Greenblatt, R.M.; Anastos, K.; Minkoff, H.; Massad, L.S.; Young, M.; Levine, A.M.; Darragh, T.M.; Weinberg, V.; Smith-McCune, K.K. Functional attributes of mucosal immunity in cervical intraepithelial neoplasia and effects of HIV infection. Cancer Res. 2004, 64, 6766-6774. [CrossRef]

55. Trimble, C.L.; Clark, R.A.; Thoburn, C.; Hanson, N.C.; Tassello, J.; Frosina, D.; Kos, F.; Teague, J.; Jiang, Y.; Barat, N.C.; et al. Human papillomavirus 16-associated cervical intraepithelial neoplasia in humans excludes CD8 T cells from dysplastic epithelium. $J$. Immunol. 2010, 185, 7107-7114. [CrossRef]

56. Maldonado, L.; Teague, J.E.; Morrow, M.P.; Jotova, I.; Wu, T.C.; Wang, C.; Desmarais, C.; Boyer, J.D.; Tycko, B.; Robins, H.S.; et al. Intramuscular therapeutic vaccination targeting HPV16 induces T cell responses that localize in mucosal lesions. Sci. Transl. Med. 2014, 6, 221ra13. [CrossRef]

57. O'Higgins, C.; Ward, F.J.; Abu Eid, R. Deciphering the Role of Regulatory CD4 T Cells in Oral and Oropharyngeal Cancer: A Systematic Review. Front Oncol. 2018, 8. [CrossRef]

58. Lin, C.M.; Lin, L.W.; Chen, Y.W.; Ye, Y.L. The expression and prognostic impact of proinflammatory cytokines and their associations with carcinogens in oropharyngeal squamous cell carcinoma. Cancer Immunol. Immunother. 2020, 69, 549-558. [CrossRef] [PubMed]

59. Castro, F.; Cardoso, A.P.; Gonçalves, R.M.; Serre, K.; Oliveira, M.J. Interferon-Gamma at the Crossroads of Tumor Immune Surveillance or Evasion. Front Immunol. 2018, 9, 847. [CrossRef] [PubMed]

60. Punt, S.; Dronkers, E.A.; Welters, M.J.; Goedemans, R.; Koljenović, S.; Bloemena, E.; Snijders, P.J.; Gorter, A.; van der Burg, S.H.; Baatenburg de Jong, R.J.; et al. A beneficial tumor microenvironment in oropharyngeal squamous cell carcinoma is characterized by a high T cell and low IL-17(+) cell frequency. Cancer Immunol. Immunother. 2016, 65, 393-403. [CrossRef] [PubMed]

61. Santegoets, S.J.; Duurland, C.L.; Jordanova, E.S.; van Ham, J.J.; Ehsan, I.; Van Egmond, S.L.; Welters, M.J.P.; van der Burg, S.H. Tbet-positive regulatory $\mathrm{T}$ cells accumulate in oropharyngeal cancers with ongoing tumor-specific type $1 \mathrm{~T}$ cell responses. $J$. Immunother. Cancer 2019, 7, 14. [CrossRef]

62. Garrido, F. MHC/HLA Class I Loss in Cancer Cells. Adv. Exp. Med Biol 2019, 1151, 15-78. [CrossRef]

63. Ou, D.; Adam, J.; Garberis, I.; Blanchard, P.; Nguyen, F.; Levy, A.; Casiraghi, O.; Gorphe, P.; Breuskin, I.; Janot, F.; et al. Influence of tumor-associated macrophages and HLA class I expression according to HPV status in head and neck cancer patients receiving chemo/bioradiotherapy. Radiother. Oncol. 2019, 130, 89-96. [CrossRef]

64. Näsman, A.; Andersson, E.; Nordfors, C.; Grün, N.; Johansson, H.; Munck-Wikland, E.; Massucci, G.; Dalianis, T.; Ramqvist, T. MHC class I expression in HPV positive and negative tonsillar squamous cell carcinoma in correlation to clinical outcome. Int. J. Cancer 2013, 132, 72-81. [CrossRef]

65. Cioni, B.; Jordanova, E.S.; Hooijberg, E.; Van Der Linden, R.; De Menezes, R.X.; Tan, K.; Willems, S.; Elbers, J.B.W.; Broeks, A.; Bergman, A.M.; et al. HLA class II expression on tumor cells and low numbers of tumor-associated macrophages predict clinical outcome in oropharyngeal cancer. Head Neck 2019, 41, 463-478. [CrossRef]

66. Locati, M.; Curtale, G.; Mantovani, A. Diversity, Mechanisms, and Significance of Macrophage Plasticity. Annu. Rev. Pathol. Mech. Dis. 2020, 15, 123-147. [CrossRef]

67. Heusinkveld, M.; De Vos van Steenwijk, P.J.; Goedemans, R.; Ramwadhdoebe, T.H.; Gorter, A.; Welters, M.J.; Van Hall, T.; Van Der Burg, S.H. M2 macrophages induced by prostaglandin E2 and IL-6 from cervical carcinoma are switched to activated M1 macrophages by CD4+ Th1 cells. J. Immunol. 2011, 187, 1157-1165. [CrossRef]

68. Veglia, F.; Perego, M.; Gabrilovich, D. Myeloid-derived suppressor cells coming of age. Nat. Immunol. 2018, 19, 108-119. [CrossRef]

69. Damuzzo, V.; Pinton, L.; Desantis, G.; Solito, S.; Marigo, I.; Bronte, V.; Mandruzzato, S. Complexity and challenges in defining myeloid-derived suppressor cells. Cytom. B Clin. Cytom. 2015, 88, 77-91. [CrossRef]

70. Mandruzzato, S.; Brandau, S.; Britten, C.M.; Bronte, V.; Damuzzo, V.; Gouttefangeas, C.; Maurer, D.; Ottensmeier, C.; Van der Burg, S.H.; Welters, M.J.; et al. Toward harmonized phenotyping of human myeloid-derived suppressor cells by flow cytometry: Results from an interim study. Cancer Immunol. Immunother. 2016, 65, 161-169. [CrossRef]

71. Lang, S.; Bruderek, K.; Kaspar, C.; Höing, B.; Kanaan, O.; Dominas, N.; Hussain, T.; Droege, F.; Eyth, C.; Hadaschik, B.; et al. Clinical Relevance and Suppressive Capacity of Human Myeloid-Derived Suppressor Cell Subsets. Clin. Cancer Res. 2018, 24, 4834-4844. [CrossRef]

72. Draghiciu, O.; Lubbers, J.; Nijman, H.W.; Daemen, T. Myeloid derived suppressor cells-An overview of combat strategies to increase immunotherapy efficacy. Oncoimmunology 2015, 4, e954829. [CrossRef]

73. Takahashi, H.; Sakakura, K.; Tada, H.; Kaira, K.; Oyama, T.; Chikamatsu, K. Prognostic significance and population dynamics of peripheral monocytes in patients with oropharyngeal squamous cell carcinoma. Head Neck 2019, 41, 1880-1888. [CrossRef]

74. Welters, M.J.P.; Ma, W.; Santegoets, S.J.A.M.; Goedemans, R.; Ehsan, I.; Jordanova, E.S.; Van Ham, V.J.; Van Unen, V.; Koning, F.; Van Egmond, S.I.; et al. Intratumoral HPV16-Specific T Cells Constitute a Type I-Oriented Tumor Microenvironment to Improve Survival in HPV16-Driven Oropharyngeal Cancer. Clin. Cancer Res. 2018, 24, 634-647. [CrossRef]

75. Wculek, S.K.; Cueto, F.J.; Mujal, A.M.; Melero, I.; Krummel, M.F.; Sancho, D. Dendritic cells in cancer immunology and immunotherapy. Nat. Rev. Immunol. 2020, 20, 7-24. [CrossRef]

76. Waisman, A.; Lukas, D.; Clausen, B.E.; Yogev, N. Dendritic cells as gatekeepers of tolerance. Semin. Immunopathol. 2017, 39, 153-163. [CrossRef] 
77. De Sousa Linhares, A.; Leitner, J.; Grabmeier-Pfistershammer, K.; Steinberger, P. Not All Immune Checkpoints Are Created Equal. Front. Immunol. 2018, 9, 1909. [CrossRef] [PubMed]

78. Bagchi, S.; Yuan, R.; Engleman, E.G. Immune Checkpoint Inhibitors for the Treatment of Cancer: Clinical Impact and Mechanisms of Response and Resistance. Annu. Rev. Pathol. 2021, 16, 223-249. [CrossRef] [PubMed]

79. Sharpe, A.H.; Pauken, K.E. The diverse functions of the PD1 inhibitory pathway. Nat. Rev. Immunol. 2018, 18, 153-167. [CrossRef] [PubMed]

80. Pauken, K.E.; Torchia, J.A.; Chaudhri, A.; Sharpe, A.H.; Freeman, G.J. Emerging concepts in PD-1 checkpoint biology. Semin . Immunol. 2021, 101480. [CrossRef] [PubMed]

81. Topalian, S.L.; Taube, J.M.; Pardoll, D.M. Neoadjuvant checkpointt blockade for cancer immunotherapy. Science 2020, 367. [CrossRef]

82. Lyford-Pike, S.; Peng, S.; Young, G.D.; Taube, J.M.; Westra, W.H.; Akpeng, B.; Bruno, T.C.; Richmon, J.D.; Wang, H.; Bishop, J.A.; et al. Evidence for a role of the PD-1:PD-L1 pathway in immune resistance of HPV-associated head and neck squamous cell carcinoma. Cancer Res. 2013, 73, 1733-1741. [CrossRef]

83. De Meulenaere, A.; Vermassen, T.; Aspeslagh, S.; Deron, P.; Duprez, F.; Laukens, D.; Van Dorpe, J.; Ferdinande, L.; Rottey, S. Tumor PD-L1 status and CD8(+) tumor-infiltrating T cells: Markers of improved prognosis in oropharyngeal cancer. Oncotarget 2017, 8, 80443-80452. [CrossRef]

84. Fukushima, Y.; Someya, M.; Nakata, K.; Hori, M.; Kitagawa, M.; Hasegawa, T.; Tsuchiya, T.; Gocho, T.; Ikeda, H.; Hirohashi, Y.; et al. Influence of PD-L1 expression in immune cells on the response to radiation therapy in patients with oropharyngeal squamous cell carcinoma. Radiother. Oncol. 2018, 129, 409-414. [CrossRef]

85. Lecerf, C.; Kamal, M.; Vacher, S.; Chemlali, W.; Schnitzler, A.; Morel, C.; Dubot, C.; Jeannot, E.; Meseure, D.; Klijanienko, J.; et al. Immune gene expression in head and neck squamous cell carcinoma patients. Eur. J. Cancer 2019, 121, 210-223. [CrossRef]

86. Sato, F.; Ono, T.; Kawahara, A.; Kawaguchi, T.; Tanaka, H.; Shimamatsu, K.; Kakuma, T.; Akiba, J.; Umeno, H.; Yano, H. Prognostic impact of p16 and PD-L1 expression in patients with oropharyngeal squamous cell carcinoma receiving a definitive treatment. J. Clin. Pathol. 2019, 72, 542-549. [CrossRef]

87. Yang, W.F.; Wong, M.C.M.; Thomson, P.J.; Li, K.Y.; Su, Y.X. The prognostic role of PD-L1 expression for survival in head and neck squamous cell carcinoma: A systematic review and meta-analysis. Oral Oncol. 2018, 86, 81-90. [CrossRef]

88. Borel, C.; Jung, A.C.; Burgy, M. Immunotherapy Breakthroughs in the Treatment of Recurrent or Metastatic Head and Neck Squamous Cell Carcinoma. Cancers 2020, 12, 2691. [CrossRef]

89. Ferris, R.L.; Blumenschein, G., Jr.; Fayette, J.; Guigay, J.; Colevas, A.D.; Licitra, L.; Harrington, K.; Kasper, S.; Vokes, E.E.; Even, C.; et al. Nivolumab for Recurrent Squamous-Cell Carcinoma of the Head and Neck. N. Engl. J. Med. 2016, 375, 1856-1867. [CrossRef]

90. Cohen, E.E.W.; Soulières, D.; Le Tourneau, C.; Dinis, J.; Licitra, L.; Ahn, M.J.; Soria, A.; Machiels, J.P.; Mach, N.; Mehra, R.; et al. Pembrolizumab versus methotrexate, docetaxel, or cetuximab for recurrent or metastatic head-and-neck squamous cell carcinoma (KEYNOTE-040): A randomised, open-label, phase 3 study. Lancet 2019, 393, 156-167. [CrossRef]

91. Ferris, R.L.; Blumenschein, G., Jr.; Fayette, J.; Guigay, J.; Colevas, A.D.; Licitra, L.; Harrington, K.J.; Kasper, S.; Vokes, E.E.; Even, C.; et al. Nivolumab vs investigator's choice in recurrent or metastatic squamous cell carcinoma of the head and neck: 2-year long-term survival update of CheckMate 141 with analyses by tumor PD-L1 expression. Oral Oncol. 2018, 81, 45-51. [CrossRef] [PubMed]

92. Ferris, R.L.; Haddad, R.; Even, C.; Tahara, M.; Dvorkin, M.; Ciuleanu, T.E.; Clement, P.M.; Mesia, R.; Kutukova, S.; Zholudeva, L.; et al. Durvalumab with or without tremelimumab in patients with recurrent or metastatic head and neck squamous cell carcinoma: EAGLE, a randomized, open-label phase III study. Ann Oncol. 2020, 31, 942-950. [CrossRef] [PubMed]

93. Davis, A.A.; Patel, V.G. The role of PD-L1 expression as a predictive biomarker: An analysis of all US Food and Drug Administration (FDA) approvals of immune checkpoint inhibitors. J. Immunother. Cancer 2019, 7, 1-8. [CrossRef] [PubMed]

94. Oguejiofor, K.; Galletta-Williams, H.; Dovedi, S.J.; Roberts, D.L.; Stern, P.L.; West, C.M. Distinct patterns of infiltrating CD8+ T cells in HPV+ and CD68 macrophages in HPV- oropharyngeal squamous cell carcinomas are associated with better clinical outcome but PD-L1 expression is not prognostic. Oncotarget 2017, 8, 14416-14427. [CrossRef] [PubMed]

95. Tsakiroglou, A.M.; Fergie, M.; Oguejiofor, K.; Linton, K.; Thomson, D.; Stern, P.L.; Astley, S.; Byers, R.; West, C.M.L. Spatial proximity between T and PD-L1 expressing cells as a prognostic biomarker for oropharyngeal squamous cell carcinoma. $\mathrm{Br}$. $\mathrm{J}$. Cancer 2020, 122, 539-544. [CrossRef]

96. Chow, L.Q.M.; Haddad, R.; Gupta, S.; Mahipal, A.; Mehra, R.; Tahara, M.; Berger, R.; Eder, J.P.; Burtness, B.; Lee, S.H.; et al. Antitumor Activity of Pembrolizumab in Biomarker-Unselected Patients With Recurrent and/or Metastatic Head and Neck Squamous Cell Carcinoma: Results From the Phase Ib KEYNOTE-012 Expansion Cohort. J. Clin. Oncol. 2016, 34, 3838-3845. [CrossRef]

97. Burtness, B.; Harrington, K.J.; Greil, R.; Soulières, D.; Tahara, M.; De Castro, G., Jr.; Psyrri, A.; Basté, N.; Neupane, P.; Bratland, A.; et al. Pembrolizumab alone or with chemotherapy versus cetuximab with chemotherapy for recurrent or metastatic squamous cell carcinoma of the head and neck (KEYNOTE-048): A randomised, open-label, phase 3 study. Lancet 2019, 394, 1915-1928. [CrossRef]

98. Palmieri, G.; Colombino, M.; Cossu, A.; Marchetti, A.; Botti, G.; Ascierto, P.A. Genetic instability and increased mutational load: Which diagnostic tool best direct patients with cancer to immunotherapy? J. Transl. Med. 2017, 15, 1-4. [CrossRef]

99. Kaidar-Person, O.; Gil, Z.; Billan, S. Precision medicine in head and neck cancer. Drug. Resist. Updat. 2018, 40, 13-16. [CrossRef] 
100. Hodges, T.R.; Ott, M.; Xiu, J.; Gatalica, Z.; Swensen, J.; Zhou, S.; Huse, J.T.; de Groot, J.; Li, S.; Overwijk, W.W.; et al. Mutational burden, immune checkpoint expression, and mismatch repair in glioma: Implications for immune checkpoint immunotherapy. Neuro Oncol. 2017, 19, 1047-1057. [CrossRef]

101. Galon, J.; Bruni, D. Approaches to treat immune hot, altered and cold tumours with combination immunotherapies. Nat. Rev. Drug Discov. 2019, 18, 197-218. [CrossRef]

102. Bruni, D.; Angell, H.K.; Galon, J. The immune contexture and Immunoscore in cancer prognosis and therapeutic efficacy. Nat. Rev. Cancer 2020, 20, 662-680. [CrossRef]

103. Kumagai, S.; Togashi, Y.; Kamada, T.; Sugiyama, E.; Nishinakamura, H.; Takeuchi, Y.; Vitaly, K.; Itahashi, K.; Maeda, Y.; Matsui, S.; et al. The PD-1 expression balance between effector and regulatory T cells predicts the clinical efficacy of PD-1 blockade therapies. Nat. Immunol. 2020, 21, 1346-1358. [CrossRef]

104. Crespo, J.; Sun, H.; Welling, T.H.; Tian, Z.; Zou, W. T cell anergy, exhaustion, senescence, and stemness in the tumor microenvironment. Curr. Opin. Immunol. 2013, 25, 214-221. [CrossRef]

105. Im, S.J.; Hashimoto, M.; Gerner, M.Y.; Lee, J.; Kissick, H.T.; Burger, M.C.; Shan, Q.; Hale, J.S.; Lee, J.; Nasti, T.H.; et al. Defining CD8+ T cells that provide the proliferative burst after PD-1 therapy. Nature 2016, 537, 417-421. [CrossRef]

106. Hudson, W.H.; Gensheimer, J.; Hashimoto, M.; Wieland, A.; Valanparambil, R.M.; Li, P.; Lin, J.X.; Konieczny, B.T.; Im, S.J.; Freeman, G.J.; et al. Proliferating Transitory T Cells with an Effector-like Transcriptional Signature Emerge from PD-1+Stem-like CD8 ${ }^{+}$T Cells during Chronic Infection. Immunity 2019, 51, 1043-1058.e4. [CrossRef]

107. Wherry, E.J.; Ha, S.J.; Kaech, S.M.; Haining, W.N.; Sarkar, S.; Kalia, V.; Subramaniam, S.; Blattman, J.N.; Barber, D.L.; Ahmed, R. Molecular signature of CD8+ T cell exhaustion during chronic viral infection. Immunity 2007, 27, 670-684. [CrossRef]

108. Im, S.J.; Konieczny, B.T.; Hudson, W.H.; Masopust, D.; Ahmed, R. PD-1+ stemlike CD8 T cells are resident in lymphoid tissues during persistent LCMV infection. Proc. Natl. Acad. Sci. USA 2020, 117, 4292-4299. [CrossRef]

109. Jansen, C.S.; Prokhnevska, N.; Master, V.A.; Sanda, M.G.; Carlisle, J.W.; Bilen, M.A.; Cardenas, M.; Wilkinson, S.; Lake, R.; Sowalsky, A.G.; et al. An intra-tumoral niche maintains and differentiates stem-like CD8 T cells. Nature 2019, 576, 465-470. [CrossRef]

110. Siddiqui, I.; Schaeuble, K.; Chennupati, V.; Fuertes Marraco, S.A.; Calderon-Copete, S.; Pais Ferreira, D.; Carmona, S.J.; Scarpellino, L.; Gfeller, D.; Pradervand, S.; et al. Intratumoral Tcf1 ${ }^{+}$PD $-1^{+} \mathrm{CD} 8^{+}$T Cells with Stem-like Properties Promote Tumor Control in Response to Vaccination and Checkpoint Blockade Immunotherapy. Immunity 2019, 50, 195-211.e10. [CrossRef]

111. Kamphorst, A.O.; Pillai, R.N.; Yang, S.; Nasti, T.H.; Akondy, R.S.; Wieland, A.; Sica, G.L.; Yu, K.; Koenig, L.; Patel, N.T.; et al. Proliferation of PD-1+CD8 T cells in peripheral blood after PD-1-targeted therapy in lung cancer patients. Proc. Natl. Acad. Sci. USA 2017, 114, 4993-4998. [CrossRef]

112. Kamphorst, A.O.; Wieland, A.; Nasti, T.; Yang, S.; Zhang, R.; Barber, D.L.; Konieczny, B.T.; Daugherty, C.Z.; Koenig, L.; Yu, K.; et al. Rescue of exhausted CD8 T cells by PD-1-targeted therapies is CD28-dependent. Science 2017, 355, 1423-1427. [CrossRef]

113. Santegoets, S.J.; Van Ham, V.J.; Ehsan, I.; Charoentong, P.; Duurland, C.L.; Van Unen, V.; Höllt, T.; Van der Velden, L.A.; Van Egmond, S.L.; Kortekaas, K.E.; et al. The Anatomical Location Shapes the Immune Infiltrate in Tumors of Same Etiology and Affects Survival. Clin. Cancer Res. 2019, 25, 240-252. [CrossRef]

114. Solomon, B.; Young, R.J.; Bressel, M.; Cernelc, J.; Savas, P.; Liu, H.; Urban, D.; Thai, A.; Cooper, C.; Fua, T.; et al. Identification of an excellent prognosis subset of human papillomavirus-associated oropharyngeal cancer patients by quantification of intratumoral CD103+ immune cell abundance. Ann. Oncol. 2019, 30, 1638-1646. [CrossRef] [PubMed]

115. Kortekaas, K.E.; Santegoets, S.J.; Sturm, G.; Ehsan, I.; Van Egmond, S.L.; Finotello, F.; Trajanoski, Z.; Welters, M.J.; Van Poelgeest, M.I.; Van Der Burg, S.H. CD39 Identifies the CD4+ Tumor-Specific T-cell Population in Human Cancer. Cancer Immunol. Res. 2020, 8. [CrossRef] [PubMed]

116. Allen, B.M.; Hiam, K.J.; Burnett, C.E.; Venida, A.; DeBarge, R.; Tenvooren, I.; Marquez, D.M.; Cho, N.W.; Carmi, Y.; Spitzer, M.H. Systemic dysfunction and plasticity of the immune macroenvironment in cancer models. Nat. Med. 2020, 26, 1125-1134. [CrossRef] [PubMed]

117. Spitzer, M.H.; Gherardini, P.F.; Fragiadakis, G.K.; Bhattacharya, N.; Yuan, R.T.; Hotson, A.N.; Finck, R.; Carmi, Y.; Zunder, E.R.; Fantl, W.J.; et al. An interactive reference framework for modeling a dynamic immune system. Science 2015, $349,1259425$. [CrossRef] [PubMed]

118. Abeler-Dörner, L.; Laing, A.G.; Lorenc, A.; Ushakov, D.S.; Clare, S.; Speak, A.O.; Duque-Correa, M.A.; White, J.K.; Ramirez-Solis, R.; Saran, N.; et al. High-throughput phenotyping reveals expansive genetic and structural underpinnings of immune variation. Nat. Immunol. 2020, 21, 86-100. [CrossRef]

119. Tonella, L.; Giannoccaro, M.; Alfieri, S.; Canevari, S.; De Cecco, L. Gene Expression Signatures for Head and Neck Cancer Patient Stratification: Are Results Ready for Clinical Application? Curr. Treat. Options Oncol. 2017, 18, 32. [CrossRef]

120. Resteghini, C.; Trama, A.; Borgonovi, E.; Hosni, H.; Corrao, G.; Orlandi, E.; Calareso, G.; De Cecco, L.; Piazza, C.; Mainardi, L.; et al. Big Data in Head and Neck Cancer. Curr. Treat. Options Oncol. 2018, 19, 62. [CrossRef]

121. Van Meir, H.; Nout, R.A.; Welters, M.J.P.; Loof, N.M.; De Kam, M.L.; Van Ham, J.J.; Samuels, S.; Kenter, G.G.; Cohen, A.F.; Melief, C.J.; et al. Impact of (chemo)radiotherapy on immune cell composition and function in cervical cancer patients. Oncoimmunology 2016, 6, e1267095. [CrossRef]

122. Schuler, P.J.; Harasymczuk, M.; Schilling, B.; Saze, Z.; Strauss, L.; Lang, S.; Johnson, J.T.; Whiteside, T.L. Effects of adjuvant chemoradiotherapy on the frequency and function of regulatory $\mathrm{T}$ cells in patients with head and neck cancer. Clin. Cancer Res. 2013, 19, 6585-6596. [CrossRef] 
123. Zheng, X.; Guo, Y.; Wang, L.; Zhang, H.; Wang, S.; Wang, L.; An, L.; Zhou, X.; Li, X.; Yao, C. Recovery Profiles of T-Cell Subsets Following Low-Dose Total Body Irradiation and Improvement With Cinnamon. Int. J. Radiat. Oncol. Biol. Phys. 2015, 93, 1118-1126. [CrossRef]

124. Clinicaltrials.gov. Available online: https://clinicaltrials.gov (accessed on 1 May 2021).

125. Doescher, J.; Minkenberg, P.; Laban, S.; Kostezka, U.; von Witzleben, A.; Hoffmann, T.K.; Schuler, P.J.; Weissinger, S.E. Immune checkpoint expression in HNSCC patients before and after definitive chemoradiotherapy. Head Neck 2021, 43, 778-787. [CrossRef]

126. Von Witzleben, A.; Fehn, A.; Grages, A.; Ezić, J.; Jeske, S.S.; Puntigam, L.K.; Brunner, C.; Kraus, J.M.; Kestler, H.A.; Doescher, J.; et al. Prospective longitudinal study of immune checkpoint molecule (ICM) expression in immune cell subsets during curative conventional therapy of head and neck squamous cell carcinoma (HNSCC). Int. J. Cancer. 2021, 148, 2023-2035. [CrossRef]

127. Welters, M.J.; Van Der Sluis, T.C.; Van Meir, H.; Loof, N.M.; Van Ham, V.J.; Van Duikeren, S.; Santegoets, S.J.; Arens, R.; De Kam, M.L.; Cohen, A.F.; et al. Vaccination during myeloid cell depletion by cancer chemotherapy fosters robust T cell responses. Sci. Transl. Med. 2016, 8, 334ra52. [CrossRef]

128. Melief, C.J.M.; Welters, M.J.P.; Vergote, I.; Kroep, J.R.; Kenter, G.G.; Ottevanger, P.B.; Tjalma, W.A.A.; Denys, H.; Van Poelgeest, M.I.E.; Nijman, H.W.; et al. Strong vaccine responses during chemotherapy are associated with prolonged cancer survival. Sci. Transl. Med. 2020, 12, eaaz8235. [CrossRef] [PubMed]

129. Massarelli, E.; William, W.; Johnson, F.; Kies, M.; Ferrarotto, R.; Guo, M.; Feng, L.; Lee, J.J.; Tran, H.; Kim, Y.U.; et al. Combining Immune Checkpoint Blockade and Tumor-Specific Vaccine for Patients With Incurable Human Papillomavirus 16-Related Cancer: A Phase 2 Clinical Trial. JAMA Oncol. 2019, 5, 67-73. [CrossRef]

130. Xu, Q.; Fang, M.; Zhu, J.; Dong, H.; Cao, J.; Yan, L.; Leonard, F.; Oppel, F.; Sudhoff, H.; Kaufmann, A.M.; et al. Insights into Nanomedicine for Immunotherapeutics in Squamous Cell Carcinoma of the head and neck. Int. J. Biol. Sci. 2020, 16, 2506-2517. [CrossRef]

131. Theodoraki, M.-N.; Yerneni, S.S.; Hoffmann, T.K.; Gooding, W.E.; Whiteside, T.L. Clinical Significance of PD-L1 ${ }^{+}$Exosomes in Plasma of Head and Neck Cancer Patients. Clin. Cancer Res. 2018, 24, 896-905. [CrossRef] 